\title{
Party Hacks and True Believers: The Effect of Party Affiliation on Political Preferences
}

\author{
Eric D. Gould and Esteban F. Klor
}

February 2017

\begin{abstract}
This paper examines the effect of party affiliation on an individual's political views. To do this, we exploit the party realignment that occurred in the U.S. due to abortion becoming a more prominent and highly partisan issue over time. We show that abortion was not a highly partisan issue in 1982, but a person's abortion views in 1982 led many to switch parties over time as the two main parties diverged in their stances on this issue. We find that voting for a given political party in 1996, due to the individual's initial views on abortion in 1982, has a substantial effect on a person's political, social, and economic attitudes in 1997. These findings are stronger for highly partisan political issues, and are robust to controlling for a host of personal views and characteristics in 1982 and 1997. As individuals realigned their party affiliation in accordance with their initial abortion views, their other political views followed suit.
\end{abstract}

JEL Classification: D72

Affiliations for the authors are: Eric Gould - Department of Economics, The Hebrew University of Jerusalem, IZA, and CEPR. Email: eric.gould@huji.ac.il; Esteban F. Klor Department of Economics, The Hebrew University of Jerusalem, and CEPR. Email: eklor@huji.ac.il.

We thank Christian Dustmann, Moses Shayo, and seminar participants at the CEPR Public Economics Annual Symposium, Hebrew University, New York University, Tel Aviv University, and Interdisciplinary Center in Herzliya for helpful comments. Zeev Goldschmidt and Rotem Horowitz provided us with outstanding research assistance. We thank The Maurice Falk Institute for Economic Research for financial support. 


\section{Introduction}

Do individuals support a political party based on their views, or are their views shaped by their party identification? This is a central question in studies on the interaction between social identity and personal preferences, dating back at least fifty years to the seminal work of Campbell et al. (1960). Several theoretical and experimental studies have raised the possibility that social context has a crucial impact on an individual's policy preferences. ${ }^{1}$ However, there is little systematic empirical research on whether there is an effect of party identification on an individual's opinions. The lack of research is likely due to the difficulty in establishing a causal connection between the two. Both are jointly determined, and therefore, a correlation between views and party affiliation reveals little about the causal relationship in any particular direction.

The idea that political affiliation affects a person's views is somewhat counterintuitive. It is natural to think that individuals choose which party to support based on their views, which results in a strong correlation between a person's opinions and party affiliation. While this is likely to be true, a substantial part of this correlation could be the result of the party's influence on the views of those who joined that party for various other reasons. For example, a person may have strong opinions about economic policies, and choose a party based primarily on which party is closest to those positions. In the process, the party may influence the person's stance on a vast array of other issues like foreign policy, criminal sentencing, judicial activism, school choice, affirmative action, school prayer, gay marriage, etc. Political parties represent a bundle of views over all issues, and it would be impossible for individuals with randomly determined views across all issues to

\footnotetext{
${ }^{1}$ See Green et al. (2002) and the references cited therein.
} 
pick a party, particularly in a two-party system, with similar views on each issue. Yet, supporters of a party often share a similar outlook over a vast array of disparate issues, and this pattern suggests that causality between party and personal views could be running in both directions.

This paper focuses on the least understood of these pathways: the extent to which party affiliation affects political opinions. In order to identify a causal relationship, exogenous variation on party preferences is required. Although a few studies have attempted to do this, their identification strategies rely on treating lagged party affiliation as exogenous [Bartels (2002), Carsey and Layman (2006)]. In contrast, we introduce a new strategy which is based on an individual's attitude towards legalized abortion, a salient issue that is generally related to one's views about when life begins versus the rights of females over their reproductive choices. A priori, it seems unlikely that a person's views on such matters should be correlated with his/her preferences on economic issues and other policy dimensions. In fact, this appears to be the case during the 1970s in the United States when the abortion issue came to the forefront of public debate. As Adams (1997) and Carmines and Woods (2002) show, the two major political parties did not stake out clear stances on abortion as of the late 1970s.

Starting in the mid-1980s, however, abortion became an increasingly partisan issue - which is in line with the idea that political parties manipulate religious issues in order to rally supporters and increase donations (Glaeser, Ponzetto and Shapiro, 2005). As the parties diverged in their stances on legalized abortion, many individuals found themselves supporting the "wrong" party in terms of their attitudes on abortion - an issue that is often deep-seated in a person's core values. Therefore, as abortion became increasingly a partisan issue, many individuals with strong beliefs on abortion in either direction were 
essentially forced to change their political affiliation in the mid-1980s and early 1990s accordingly. $^{2}$

Using detailed panel data containing the political views of each respondent in 1982 and 1997 on a variety of issues, we show that the abortion stance of an individual in 1982 did cause party switching between 1980 and 1996. Holding a pro-life view in 1982 doubled the probability (12 percent to 24 percent) that a Democratic voter in 1980 switched his/her support to the Republicans in 1996. Holding a pro-life view in 1982 increased the chances that a Republican voter in 1980 stayed Republican in 1996 by 22 percentage points. To see if the new party affiliation affected the person's views on issues other than abortion, let us consider the example of a person's opinion about marijuana legalization. Our basic strategy is to control for an individual's personal characteristics, including their view about marijuana legalization in 1982, and test whether the individual's political affiliation in 1996 (as explained by his or her initial attitudes on abortion in 1982) affects their view about marijuana legalization in 1997 . We perform a similar analysis for a host of other political, social, and economic issues.

The results show that individuals not only changed their party as of 1997 in accordance to their abortion views in 1982, but this party realignment led individuals to shift their preferences over other policy dimensions accordingly. That is, as people switched parties due to their initially held abortion views, their other political views tended to follow suit. These findings hold for a variety of political, economic, and social

\footnotetext{
${ }^{2}$ The reasons that led the parties to adopt the positions on abortion that they adopted, and to diverge over time, are beyond the scope of our study. See Brady and Schwartz (1995) and Carmines and Woods (2002) for studies highlighting the role that party activists and party elites played on the evolution of abortion as a partisan issue.
} 
issues that are not directly related to abortion, but are stronger for issues that are more partisan in nature.

Our empirical strategy relies on the assumption that individuals were more likely to change their party identification than their abortion views. This assumption is consistent with a large body of evidence showing that an individual's abortion views tend to be constant over time [Converse and Markus (1979), Tatalovitch and Schier (1993), Wilcox and Riches (2002), Jelen and Wilkox (2003), and Carsey and Layman (2006)]. The high correlation of abortion views over time is present in our data - 76 percent of the individuals in our sample hold the same abortion view between 1982 and 1996, while only 53 percent voted for the same party. The strength of this correlation is probably due to the idea that abortion views tend to be based on deeply held religious beliefs. In addition, this issue is framed as a clash of two opposite absolutes, making it difficult for individuals to change their minds (Maxwell, 2002). Therefore, the sudden divergence in party platforms regarding abortion offers a unique opportunity to see whether this process induced individuals to switch parties, and whether that switch caused individuals to realign their views on other issues according to the new party line.

Our study is closely related to the rapidly growing theoretical literature on the relationship between a person's social identity and his/her personal preferences [see, among many others, Akerlof and Kranton (2000), Beck et al. (2002), and Shayo (2009)]. This literature is based on the insights of Tajfel and Turner $(1979,1986)$ regarding social identity. They show that an individual's political preferences are not only affected by their own self-interest, but also by their social context and the social groups they choose to identify with. These theoretical advances had been accompanied mostly by experimental evidence showing that social identity affects an individual's preferences over 
redistribution [Luttmer (2001) and Klor and Shayo (2010)] and level of altruism [Fowler and Kam (2007) and Fong and Luttmer (2009)]. Our study contributes to this literature by examining the way that a person's political party affiliation, which is often an important component of one's social identity, influences a person's views on a vast array of topics. We show that voting for a party induces individuals to adapt their views to the positions of a prototypical member of the group they choose to identify with. ${ }^{3}$

Our paper is also related to important studies by Mullainathan and Washington (2009) and Gerber et al. (2010), which analyze the possibility that views are affected by increased political participation. ${ }^{4}$ Mullainathan and Washington (2009) compare the views of individuals who were eligible to vote in a presidential election to those that were just shy of the eligible age. They find that those who were eligible to vote had stronger views than those that were ineligible. They interpret this finding as evidence of cognitive dissonance - individuals mentally adjusted their views to coincide with their previous

\footnotetext{
${ }^{3}$ In a recent related experimental study, McCauley (2014) shows that priming different identities in Africa leads individuals to alter their preferences over policy. McCauley's (2014) findings occur in the laboratory and without any time elapsed between treatment and survey. We observe similar effects in the field. We also find that the effects are persistent over time, since the treatment is fifteen years apart from the survey measuring outcomes.

${ }^{4}$ Carsey and Layman (2006) empirically address the issue in our study, but use an empirical strategy based on the timing of party and preference changes. They estimate two structural equations which capture the causality of party identification on views and vice versa. Their strategy is based on using lagged partisanship to estimate the effect on current views. A similar strategy is used in Bartels (2002). However, as argued by Gerber et al. (2010), existing studies do not have exogenous party identification, and therefore, are likely to suffer a bias from omitted variables and reverse causality. In contrast, our strategy is based on the idea that abortion views during the 1970s and 1980s were not correlated with party identification, but are correlated with changing parties in the future as abortion became a partisan issue. This exogenous information about party switches enables us to estimate the causal effect of party identification on political views.
} 
voting behavior. Gerber et al. (2010) find further evidence that partisanship is affected by political activity using a field experiment. Before a primary in Connecticut, the researchers sent reminders to independent voters with partisan leanings that they need to register for a party in order to participate in that party's primary election. They found that individuals who received the reminder were more likely to register for a party and identify with that party than a control group of similar individuals who did not receive the reminder. They did not find an effect of increased partisanship on an individual's policy opinions, probably due to the short time elapsed between the treatment and the survey.

Mullainathan and Washington (2009) and Gerber et al. (2010) demonstrate that individuals are more likely to hold stronger and more consistent views over time if they invest more effort in their political participation and in acquiring information. In contrast, our paper focuses on how an individual's party identification affects a person's views. Individuals that switch parties because of their views on one issue do not have to adapt their views on other issues, yet they tend to do so. Cognitive dissonance is one factor that could explain why a person's views are shaped by party affiliation across a wide array of issues. Individuals may derive disutility from supporting a party that is at odds with their views on various issues, and therefore, may adapt their stances in order to increase their attachment to the new party. It is also possible that individuals supporting a new party become more open and exposed to partisan political information and argumentation, which leads them to alter their pre-existing views.

Hence, a review of the literature shows that there is little evidence on the causal effect of party affiliation on an individual's attitudes. Recent evidence does show that increased political participation and information strengthens an individual's identification with the political party that he or she supports. We build on these findings by showing 
how party affiliation impacts an individual's preferences over a wide array of political, economic, and social issues.

\section{Data}

Our main data source is a panel data set drawn from the Inter-University Consortium for Political and Social Research (ICPSR). This data set, called "YouthParent Socialization Panel Study, 1965-1997: Four Waves Combined,” is a longitudinal study of a national sample from the graduating high school class of 1965 . It contains information on their evolving political, social, and economic preferences for the years $1965,1973,1982$, and $1997 .^{5}$ All of the individuals in the survey were between 17 and 19 years old in 1965, and therefore, can be considered part of the same cohort.

The surveys conducted by the "Youth-Parent Socialization Panel Study" focus on a wide array of substantive issues affecting American society. These include questions on economic and political values, trust in government, social welfare, and the desired relationship between state and religion, among many others. There are, in addition, several questions regarding the political preferences of the respondent and his or her preferred policy position regarding the issue of abortion. Our analysis uses the surveys of 1982 and 1997, because these are the only waves which contain information about the respondent's attitude towards abortion.

\footnotetext{
${ }^{5}$ General information on these surveys, including methodology, the wording of the questions, and summary results are available from http://www.icpsr.umich.edu/icpsrweb/ICPSR/studies/04037. See also Jennings et al. (2004).
} 
There are two main variables of interest, which are computed separately for the two available years. The first variable relates to the respondent's abortion position. The question about abortion attitudes is worded as follows:

There has been some discussion about abortion during recent years. Which one of the opinions on this page best agrees with your view? You can just tell me the number of the opinion you choose.

1. By law, abortion should never be permitted.

2. The law should permit abortion only in case of rape, incest, or when the woman's life is in danger.

3. The law should permit abortion for reasons other than rape, incest, or danger to the woman's life, but only after the need for the abortion has been clearly established.

4. By law, a woman should always be able to obtain an abortion as a matter of personal choice.

Answers to this question in the 1982 survey were used to categorize an individual's stance on abortion in the initial period. Out of 923 respondents, the distribution of answers was: (1) 6.93 percent; (2) 20.69 percent; (3) 25.89 percent; and (4) 46.48 percent. We classify an individual as being anti-abortion if he or she chose answers 1,2 , or $3 .^{6}$ This definition results in 53.52 percent of the sample characterized as "prolife" in 1982. ${ }^{7}$ Adams (1997) reports a remarkably similar percentage of pro-life individuals using a similar definition and data from the General Social Survey (see Figure A.1 in the Appendix).

\footnotetext{
${ }^{6}$ Dropping from the analysis individuals who chose option 3 does not affect any of our results.

${ }^{7}$ This paper does not adopt a normative view on the abortion debate. For ease of exposition, we follow the Merriam Webster definition and call individuals that are against legalizing abortion on demand as "pro-life" individuals. Similarly, following the Merriam Webster definition of the term, we define as "pro-choice" those individuals that favor the legalization of abortion with the least amount of restrictions.
} 
We observe almost the same distribution of attitudes regarding abortion according to the 1997 survey. The distribution of responses in 1997 is: (1) 7.91 percent; (2) 22.32 percent; (3) 23.73 percent; and (4) 46.05 percent. This results in 53.95 percent of individuals being defined as pro-life.

The second variable of interest is whether or not an individual voted for the Republican Party in the previous presidential elections. This question refers to the elections of 1980 for the 1982 survey and to the elections of 1996 for the 1997 wave. The actual wording of the question is: "Who did you vote for in the presidential election?" $1980,53.46$ percent of the sample voted for the Republican Party, which dropped to 40 percent in $1996 .{ }^{9}$ The correlation of the Republican vote between these two elections equals 0.41 .

In addition, we examine a wide array of political, social, and economic attitudes that were consistently defined in the 1982 and 1997 waves of the survey. As seen in Table 1, these include attitudes on social issues like marijuana, prayer at school, a woman's role in society, and general trust in the government. They also cover attitudes on the role of government in society -- whether or not the government should racially integrate schools,

\footnotetext{
${ }^{8}$ Respondents mentioned six different answers in the 1982 survey: Reagan (45.37\% of the sample), Carter (29.47\%), Anderson (11.6\%), Other (1.3\%), Would have voted for Reagan (8.08\%), Would have voted for Carter (4.17\%). We pooled "Reagan" and "Would have voted for Reagan" as Republican supporters. Respondents mentioned four different answers for the elections of 1996: Dole (40.02\%), Clinton (52.12\%), Perot (6.36\%), Other (1.5\%). None of our results is affected if: (i) individuals who answered "Other" are dropped from the sample; (ii) individuals who voted for Ross Perot in 1996 are dropped from the sample or considered to be supporters of the Republican Party; or (iii) we use "support for the Democratic party" as the explanatory variable instead of supporting the Republican party.

${ }^{9}$ This reflects the fluctuations of the overall US electorate between those two elections. Reagan obtained 50.8 percent of the popular vote in 1980 and Bob Dole obtained 40.7 percent of the popular vote in 1996.
} 
help minorities, stop crime, pay attention to public opinion, play a leading role in foreign affairs, and whether or not the government wastes money. Finally, we use attitudes on economic issues like whether the government should provide jobs, be responsible for the benefit of all citizens, and whether the respondent thinks that unions and big business have too much influence.

Table 1 presents summary statistics for each attitude, where each one is defined as a dummy variable equal to one if the respondent holds the position closer to the view of the Republican Party. This table shows that the sample population is almost equally partitioned in terms of abortion attitudes and party lines. Moreover, it is almost equally divided in terms of their overall political, social, and economic attitudes for both waves of the survey. For example, according to the 1982 survey, around 45 percent of the respondents see themselves as conservatives, think that marijuana should not be legal, think that women should not have an equal role with men, and do not trust the government. These views are consistent over time.

A majority of the respondents seem to have a view more in line with that of the Republican Party when asked about the government's role in society and their attitudes on economic issues. Over 60 percent of the sample thinks that the government should not be responsible for racially integrating schools or providing jobs, and that it wastes a lot of money. That said, some of these attitudes show a great deal of variation over time. Whereas almost 62 percent of the individuals thought that the government is not responsible for racially integrating schools in 1982, only 43 percent of them held this view in 1997. Similarly, we see a substantial drop of over 27 percentage points between 1982 and 1997 in the share of individuals who think that unions have too much influence. 
The table also depicts a strong persistence of individual attitudes on abortion over time. This is reflected in a correlation of 0.593 on abortion views over time at the individual level. This is the highest correlation for any of the available attitudes, seconded by whether public schools should be allowed to start each day with prayer, which has a correlation of 0.546 .

The high persistence of abortion views, which is at the heart of our identification strategy, corroborates similar results by Converse and Markus (1979) based on a CPS panel study in the 1970s. They showed that views on abortion and the legality of marijuana are the most persistent issues. The remarkable stability of abortion attitudes is also supported by numerous studies using different methodologies and data sets [see, among many others, Tatalovitch and Schier (1993), Wilcox and Riches (2002), Jelen and Wilcox (2003) and Carsey and Layman (2006)]. Wetstein $(1993,1996)$ and Wilcox and Riches (2002) argue that views on abortion are stable because this issue has been controversial since 1973, and it has been framed as a clash of absolutes between the privacy rights of a pregnant woman to choose whether or not to have an abortion versus the right of the fetus to life. Therefore, not only do most individuals have strong beliefs on this issue, but they also find it difficult to change their attitudes on the legality of abortion due to the inexistence of a middle ground in the surrounding public discourse (Maxwell, 2002).

Table 2 presents summary statistics by survey year and party support, which we use to measure the degree of partisanship for every attitude. The table compares the proportion of individuals holding a particular attitude that voted for the Republican Party in the previous presidential elections to the proportion of individuals who hold the same 
attitude but didn't vote for the Republican Party in the previous elections. We define the difference in proportions between the two groups as the attitude's degree of partisanship.

Table 2 shows that there are stark differences in political views between supporters of each party in the survey of 1982. Substantial differences across party lines are found for views on abortion, legality of marijuana, women's role in society, racial integration of schools, helping minorities, and the government's responsibility to provide jobs. The exceptions to this partisan divide are an overall agreement that the government wastes money, that the government pays attention to public opinion, and to a lesser degree, that the government should not play a leading role in the affairs of other countries.

The results for the 1997 survey depict a similar picture. If anything, the degree of partisanship for most attitudes increased over time. Importantly, a comparison of the surveys shows that trust in government and views on whether the government is run for the benefit of all depend on the political affiliation of the president at the time. Republicans voters trust (distrust) the government and believe that it is (not) run for the benefit of all when the president belongs to the Republican (Democratic) Party.

In addition to the variables listed in Tables 1 and 2, the survey contains detailed personal information on each respondent such as: age, gender, ethnicity, education, state of residence, state of birth, and employment status. Table 3 presents summary statistics for these variables, and shows that our sample is predominantly white and highly educated, with high levels of employment in 1997 (all individuals are between 49 and 51 years old in 1997). The geographic distribution in terms of state of birth is highly representative of the overall US population, as is the observed migration to the Pacific and South Atlantic regions, which is seen by their state of residence in 1997. 


\section{Empirical Strategy}

Our empirical strategy is designed to identify the causal effect of party support on an individual's political, social, and economic attitudes. The unit of observation is the individual, and we model her attitude on each issue in 1997 as a function of her personal characteristics, state of residence, state of birth, her attitude on the same issue in 1982, and whether she voted for the Republican Party in 1996. Formally, we estimate the following linear model:

$$
\begin{aligned}
& (\text { Individual Attitude })_{i, 97}=\alpha(\text { Individual Attitude })_{i, 82}+\beta(\text { Voted Republican })_{i, 96}+\mathbf{X}_{i, 97} \Phi \\
& +\mu_{s}+\varepsilon_{i}
\end{aligned}
$$

where (Individual Attitude) ${ }_{i, t}$ is a binary indicator for whether individual $i$ holds the given attitude (as stated in Table 1) according to the survey taken in year $t$ (where $t$ equals 1982 or 1997); (Voted Republican) $)_{i, 96}$ is a binary indicator for whether individual $i$ voted for the Republican Party in the 1996 presidential elections; and $\mathbf{X}_{i, 97}$ is a vector of individual and city level characteristics. This vector includes the individual's race, gender, education, and employment status as reported in 1997. It also includes fixed-effects for the individual's state of birth and the size category of the city of residence in $1982 .{ }^{10} \mu_{s}$ is a fixed-effect for the individual's current state of residency $s$. The error term is given by $\varepsilon_{i}$. Note that since (Individual Attitude) ${ }_{i, 82}$ is included on the right-hand side, model (1)

\footnotetext{
${ }^{10}$ The survey divides city of residence of respondents into 10 categories. These are: up to 2,500; 2,500 9,$999 ; 10,000$ - 29,999; 30,000 - 49,999; 50,000 - 99,999; 100,000 - 149,999; 150,000 - 349,999; 350,000 - 499,999; 500,000 - 999,999; 1,000,000 or more. The empirical analysis includes fixed effects to control for these categories.
} 
estimates the effect of voting Republican on changes in the individual's attitude between 1982 and 1997. ${ }^{11}$

The goal of the proposed econometric specification is to identify $\beta$, which represents the effect of party affiliation on an individual's views. As discussed above, there are a number of reasons why OLS estimation of equation (1) is likely to yield inconsistent estimates of our parameter of interest. First, there may be reverse causality whereby an individual's point of view leads her to vote for the Republican Party. In addition, there are many omitted determinants of an individual's political attitudes that will naturally be correlated with her voting patterns. Finally, the estimates may be biased due to measurement error, which may arise because an individual's recollection of her voting behavior a year or two after an election is potentially a noisy measure of her actual behavior. For example, it is possible that some Republicans might claim to have voted for Clinton over Dole in the 1996 elections, even if they did not. Therefore, while reverse causality and omitted variable bias may produce an upward bias in our estimate of $\beta$, measurement error of the type described above could potentially have the opposite effect.

We address these issues by using an individual's view about abortion in 1982 as an instrument for supporting the Republican Party in 1996. The exclusion restriction implied by this strategy is that an individual's stance on abortion in 1982 affects her other political views in 1997 only through the person's choice of which party to support - after

\footnotetext{
${ }^{11}$ In addition to all the controls included in model (1), the appendix presents results when we also control for (Voted Republican $_{i, 80}$, a binary indicator for whether individual $i$ voted for the Republican Party in the 1980 presidential elections. We relegate this specification to the appendix because adding (Voted Republican) $)_{i, 80}$ to the model decreases the number of observations by roughly a hundred individuals. Importantly, this specification delivers the same qualitative and quantitative results.
} 
controlling for the person's views on the same issue in 1982 and the other personal and state-level characteristics described above.

The identification strategy is based on three main ideas: (1) It took several years for political parties to adopt clear, differentiated positions on abortion; (2) Abortion is a core issue that many individuals are unwilling to consider changing their minds about; and (3) As the parties diverged on their abortion stances, some individuals found themselves supporting the "wrong" party in terms of their views on abortion. As a result, many individuals switched their party allegiance rather than changing their abortion stance. Our empirical strategy evaluates how the change in party affiliation, caused by the abortion realignment, affected those individuals in terms of their views on other political issues.

We now assess the evidence for the first two ideas mentioned above, as the third one is implied by the first two. Support for the emergence of abortion as a partisan issue in the mid-1980s is prevalent in the existing literature. For example, Adams (1997) uses roll call votes in Congress to compute a yearly score for each party based on the proportion of pro-choice votes out of total abortion votes cast for that year. He finds that the proportion of pro-choice votes of Democratic congressmen was less than $30 \%$ in 1973 , and remained around $50 \%$ until the mid $1980 \mathrm{~s}$. This proportion steadily rose in the late 1980s and reached $90 \%$ in 1994 , the last year of his analysis. Contrary to Democratic representatives, the proportion of Republican congressmen with pro-choice votes is relatively constant around $20 \%$ for the entire period analyzed (1973 to 1994). Hence, while the difference on abortion attitudes between Democrats and Republicans is not 
substantial until the mid 1980s, a big divergence occurred thereafter [see Adams (1997), Figures $1 \mathrm{~A}$ and $1 \mathrm{~B}$ in pages $723-724]^{12}$

We use data from the American National Election Studies (ANES) to provide additional evidence for the divergence of the two parties on the issue of abortion in the 1980's. ${ }^{13}$ For each year and each party, Figure 1 shows the coefficient from a regression of an indicator for supporting that party in the most recent national election on a dummy for having a "pro-choice" view on abortion. We classified individuals as pro-choice if they stated that "by law, a woman should always be able to obtain an abortion as a matter of personal choice."

The figure depicts a clear pattern whereby support for the Democratic or Republican Party in national elections is not statistically related to their abortion stance between 1972 and 1984. After 1984, the estimated coefficients for supporting the Democratic Party diverge from the coefficients estimated for the Republican Party, and both are statistically different from zero. After the mid 1980s, therefore, a strong relationship emerges between an individual's attitude on abortion and his or her voting behavior. Accordingly, a substantial majority of individuals with pro-choice views support the Democratic Party and a substantial majority of individuals with a pro-life view support the Republican Party. Therefore, Figure 1 illustrates how abortion was not a

${ }^{12}$ Brady and Schwartz (1995), Tatalovich (1997), and Carmines and Woods (2002), among many others, provide very similar evidence.

${ }^{13}$ The American National Election Studies are a collection of surveys of a representative sample of the American population, which is conducted every two years. The surveys cover topics very similar to the ones covered by "Youth-Parent Socialization Panel Study, 1965-1997: Four Waves Combined," the data we use in the current paper. These include individuals' voting behavior, and their attitudes on other social and political issues. See ANES website (http://www.electionstudies.org) for a thorough description of the surveys and the available data. 
partisan issue in the 1970's and early 1980's, but quickly became a point of major contention between the two parties in the mid-1980's. ${ }^{14}$

The Youth-Parent Socialization Panel Study provides evidence for the idea that people are reluctant to change their abortion views over time. As noted above, Table 1 shows that the correlation of an individual's view on abortion between 1982 and 1997 is substantially higher than the correlation for any of the other attitudes of interest. In particular, over 75 percent of the individuals in our sample keep the same abortion stance over the fifteen years between 1982 and 1997. As already mentioned above, numerous studies also find that an individual's views on abortion are remarkably stable [see, for example, Converse and Markus (1979), Tatalovitch and Schier (1993), Wetstein (1993, 1996), Wilcox and Riches (2002) and Jelen and Wilcox (2003)].

Given the stability of individual views on abortion, the divergence of the two parties on the issue of abortion over time created a situation where many individuals were supporting a party which disagreed with them on a fundamental and highly personal issue. In response, many pro-choice individuals that used to support the Republican Party shifted their support towards the Democratic Party, whereas pro-life individuals tended to shift their support towards the Republican Party. Panel A in Figure 2 shows that individuals with pro-life views in 1982 that voted for the Republican Party in 1980 were 18 percentage points more likely to stay with the Republican Party in 1996 relative to those that were pro-choice. Panel B of the figure shows that being pro-life in 1982 doubles the

\footnotetext{
${ }^{14}$ Similar evidence on the realignment on individuals across party lines based on their abortion attitudes appears in Adams (1997), Carmines and Woods (2002), Carsey and Layman (2006), and Killian and Wilcox (2008). In the appendix we extend the evidence in Adams (1997), which used data from the General Social Survey and covered the period 1972 to 1994, to the period 1972-2004.
} 
chances that a Democrat in 1980 switched over to support the Republican Party in 1996. We use this political realignment as a source of variation in party affiliation to examine the effect of partisanship on a person's political views on issues other than abortion.

\section{Results for Various Political Views}

\section{A. Overall Political Views}

Table 4 presents the impact of party identification on an individual's selfcharacterization as having conservative views. ${ }^{15}$ The first column of Table 4 presents OLS estimates of the effect of voting for the Republican Party in 1996 on identifying oneself as conservative in 1997, when controlling only for the individual's selfidentification as having conservative views in $1982 .{ }^{16}$ As expected, we observe a high correlation between voting for the Republican Party in 1996 and holding a conservative view in 1997. Nevertheless, for reasons mentioned above, we cannot interpret this correlation as causal. This column also shows that there is a high persistence of political views over time (the same attitude in 1982 is highly significant). ${ }^{17}$

The second column of Table 4 shows the reduced form equation, which regresses the individual's attitude in 1997 on the same attitude in 1982 and her abortion stance in 1982. The estimated coefficients confirm that the individual's view on abortion in 1982

\footnotetext{
15 We define an individual as having conservative views if he or she sees him or herself as slightly conservative, conservative, or extremely conservative. The other possible answers to this question are seeing oneself as moderate, slightly liberal, liberal, or extremely liberal.

${ }^{16}$ We estimate all our models as linear probability models for simplicity and ease of interpretation of the coefficients, even though the dependent variable is binary. None of our qualitative or quantitative conclusions are affected when we use a probit or logit model instead.

17 Table A1 in the appendix of the paper shows that the results of Table 4 are robust to including as a covariate voting for the Republican Party in 1980. As already mentioned above, we relegate these results to the appendix because this variable is not available for over a 100 individuals (about a $15 \%$ of the sample).
} 
has a significant and substantial effect on holding a conservative view in 1997, even after controlling for the individual's conservative view in 1982. In particular, column 2 shows that individuals with pro-life attitudes in 1982 are 14.5 percentage points more likely to hold a conservative view in 1997 than pro-choice individuals even after controlling for this attitude in 1982. These results provide a strong indication that individuals shifted their overall political outlook according to their abortion views in 1982, as abortion became a partisan issue.

Column 3 shows the first stage in two-stage least squares with abortion views in 1982 as the instrument for voting Republican in 1996. The coefficient suggests that individuals with a pro-life attitude in 1982 are over 15 percentage points more likely to vote for the Republican Party in 1996, conditional on whether the person held a conservative outlook in 1982. The effect is highly statistically significant (the $F$-statistic is higher than 10) and considered sufficiently strong (Stock et al., 2002). As shown in Table A.1 in the appendix, the magnitude and significance of this coefficient is similar after controlling for whether the individual voted Republican in 1980. This is consistent with the evidence presented by Adams (1997), Carmines and Woods (2002), Carsey and Layman (2006), and Killian and Wilcox (2008) claiming that the abortion issue produced a realignment of the electorate across party lines in the 1980s and 1990s.

Column 4 presents the 2SLS estimates of interest. This column shows that voting for the Republican Party in 1996 leads individuals to adopt a conservative view. The results are significant statistically and in terms of magnitude. The size of the coefficient implies that a standard deviation increase in the likelihood of supporting the Republican Party increases the chances of holding a conservative view by 0.44 percentage points.

Columns 5 to 8 of Table 4 repeat the estimations of columns 1 to 4 but control for individual characteristics that may be correlated with a person's political and abortion attitudes. These variables include gender, race, employment status, education, current city 
of residence population size, and fixed-effects for current state of residence and state of birth. These columns show that white men are more likely to hold conservative views and that these views are not correlated with employment status or education. Remarkably, all the estimated coefficients in columns 5 to 8 are similar to those estimated in columns 1 to 4. Column 7 shows that pro-life views on abortion in 1982 lead people to vote for the Republican Party in 1996, while the 2SLS estimate on the effect of voting Republican in 1996 in column 8 is similar to the estimate without additional controls in column 4 . The larger coefficients for 2SLS versus OLS suggest that measurement error causes OLS coefficients to be biased downwards rather than biased upwards due to reverse causality or omitted variables. $^{18}$

Overall, Table 4 shows that abortion views led people to vote for a given political party, and individuals responded by aligning their overall views with their party. This finding is consistent with Mullainathan and Washington (2009) who show that voting for a candidate leads to a more favorable opinion of that candidate in the future. In the next section, we show that voting for a political party leads to a change not only in general political attitudes, but also in a person's specific economic and social views as well.

\section{B. Social Attitudes}

Table 5 presents the estimated effects of party identification on attitudes regarding social issues. The outcomes include a person's stance on the legality of marijuana, school prayer in public schools, and whether women should have an equal role in society. While views on abortion could potentially affect an individual's social attitudes, our exclusion restriction is still satisfied if, controlling for the individual's demographic characteristics,

\footnotetext{
18 The fact that adding covariates doesn't affect the estimated coefficients of interest is already a strong indication that these coefficients are not substantially affected by omitted variable bias (Altonji et al., 2005).
} 
views on abortion in 1982 only affect changes in her social attitude between 1982 and 1997 through her voting for a giving political party in 1996.

The results of Table 5 confirm that views on abortion in 1982 led individuals to support a given party in 1996 and to adopt the party's stance on these other social issues. The reduced form models in columns 2, 6, and 10 confirm that pro-life views in 1982 have a significant and substantial effect on social views in 1997 even after controlling for the individual's stance on the same issue in 1982. We see that a pro-life view in 1982 causes an increase of almost 11 percentage points in the likelihood that individuals oppose the legalization of marijuana and that women should have an equal role in society as men, both measured in 1997. A pro-life view in 1982 increases the chance that a person supports prayer in public schools in 1997 by 14 percentage points.

The IV results in columns 4,8 , and 12 of Table 5 suggest that the reduced form findings mentioned above stem from the effect of abortion views in 1982 on a person's political affiliation in 1996. A standard deviation increase in partisanship increases the likelihood that an individual adopts the party's views on social issues by a range of 36 percentage points (regarding women's role in society) to 52 percentage points (regarding prayer at public schools). The strong effect of party affiliation on social views is not surprising since, as shown in Table 2, these are hot-button issues that are highly partisan in nature in both periods.

\section{The Role of Government in Society}

Table 6 estimates the effect of voting for the Republican Party on attitudes regarding the role of government in society. A priori, one would think that views on abortion in 1982 should not have a significant effect on an individual's opinions 15 years later regarding: trust in government, whether the government should help minorities, or whether the government should provide jobs and ensure a good standard of living. This is 
especially true since we control for the person's view on each issue as of 1982 . Yet, as shown in the reduced form models of Table 6, a pro-life view on abortion in 1982 has a significant effect on these views in 1997, and these effects range between 7.3 to 12 percentage points. Again, as with Tables 4 and 5, the reduced form effect is working through a realignment in the individual's party affiliation (columns 3, 7 and 11), which produces a commensurate shift on their attitudes regarding the role of government in society. While the strength of these findings may be surprising, it is important to note that these are also highly partisan issues (Table 2). As a consequence, individuals may experience a cognitive dissonance cost if they vote for a party without sharing the party's views on these other highly contentious issues.

\section{Economic Attitudes}

This subsection analyzes outcomes regarding the individual's views on unions, big business, and the size of the government. This analysis is based on arguably the most compelling evidence regarding the exclusion restriction. A priori, there is no reason to believe that views on abortion are correlated with views on unions, big business, or the size of the government. If anything, individuals supporting the right of the government to interfere with a person's reproductive decisions by restricting or banning access to abortion should also be a likely candidate to favor bigger and more intrusive government interventions in other areas. This, of course, is contrary to reality, where individuals that have pro-life attitudes also tend to favor a smaller government. We argue that this correlation is caused by these views being bundled by the Republican Party. Of course, the same argument applies to having a pro-choice attitude and preferring a bigger government, which are bundled into the platform of the Democratic Party.

The reduced form estimates in Table 7 show that there is a positive correlation between pro-life views in 1982 and holding a Republican point of view on economic 
attitudes (see columns 2, 6, and 10). Note also that the views on abortion in 1982 have a significant and substantial effect on voting for the Republican Party in 1996 (the first stage regression), even after controlling for the individual's attitudes on economic issues in 1982 (columns 3, 7, and 11). Finally, the results of the second stage confirm that identifying with a given party increases the likelihood that the individual adopts the party's view on unions, big business, and the size of the government.

\section{E. Non-Partisan Issues}

Table 8 presents the results of voting for the Republican Party on a person's views about issues that are not partisan in nature. As discussed above, an issue is considered non-partisan if holding a particular view is not correlated with voting for a particular

party. Based on the evidence presented in Table 2, we define an issue as non-partisan if the difference between the proportion of individuals holding a particular attitude that voted for the Republican Party and the proportion of individuals who hold the same attitude but didn't vote for the Republican Party is not statistically different from zero at the 1 percent level for both waves of the survey. For example, over 70 percent of the sample agrees that the government wastes a lot of money, regardless of party affiliation. The same is true for believing that the government "is not run for the benefit of all." Similarly, believing that the "government pays attention to people's thoughts" is related to whether a person supported the party that won the previous election rather than a particular party. In other words, Republicans held this view more often in 1982, and this reversed itself after Clinton won in 1996.

Using these non-partisan views as outcomes serves as a placebo analysis. Individuals should not experience disutility from cognitive dissonance regarding these issues when they switch party allegiance, since their new party does not hold a strong 
stance on the issue anyway. Therefore, party affiliation in 1997 (as explained by abortion attitudes in 1982) should not have a strong effect on these attitudes.

The results of Table 8 confirm the predictions above. Even the simple OLS

estimates in columns 1, 5, and 9 show that voting for the Republican Party in 1996 is not correlated with non-partisan attitudes. Therefore, even though we still observe very strong first-stage coefficients in columns 3, 7, and 11 (abortion views in 1982 still predict party affiliation in 1997), the second stage regressions confirm that party affiliation fails to explain shifts in attitudes on non-partisan issues.

\section{Alternative Mechanism for the Effect of Partisanship on Attitudes}

A possible concern with the assumption behind our exclusion restriction is that views on abortion are correlated with unobserved characteristics of the individual, which may affect the relationship between partisanship and political attitudes. For instance, a vast literature in political science has documented increasing polarization among political parties and voters (see, for example, Hare and Poole, 2014). Thus, one would expect that individuals who were slightly more conservative (liberal) than the median voter in 1982 to have become more conservative (liberal) by 1997 as parties become more polarized over time. This should increase the likelihood that they vote for the Republican (Democratic) Party in 1996 and express more conservative (liberal) views on a number of other domains as well. According to this possibility, our coefficients would not reflect the partisanship effect on attitudes but the effect of political polarization.

If the polarization of the political map is the main force behind our results, then other social views in 1982 aside from one's abortion stance in 1982, should also predict party switching and the adoption of more partisan positions as of 1997 . Table 9 addresses 
this alternative hypothesis. The table studies whether other social attitudes in 1982 are correlated with party switching (the first stage of our analysis). Views on the legality of marijuana, allowing prayer in public schools, and women's role in society are very partisan issues in 1982 (see the evidence in Table 2) and remain highly partisan in 1997 (see Table 2 and columns 1, 5 and 9 in Table 5). However, the table clearly shows that abortion is the only social issue measured in 1982 that predicts party switching by 1996 . The estimated effect of abortion is statistically significant, of an important magnitude, and does not dissipate even when all four social attitudes are included in the same specification. These findings support our identifying assumption that abortion led to realignment across political parties. As individuals switched parties due to their views on abortion, their other political, social, and economic attitudes followed suit.

\section{External Validity of the Estimated Effects}

The coefficients estimated using model (1) report the local average treatment effects (LATE) of partisanship on individuals' attitudes. This is the effect estimated from the subpopulation of compliers. That is, pro-life individuals in 1982 that switched their vote to the Republican Party in 1996, and pro-choice individuals in 1982 that switched their vote to the Democratic Party in 1996. As with any IV estimation, there is a concern that the subpopulation of compliers is substantially different from the rest of the population (Imbens and Angrist, 1994). If this is the case, the average effect of partisanship on attitudes in the population may differ from the effect on the subpopulation of compliers.

Table 10 addresses this concern. This table compares the demographic characteristics of compliers to the rest of the population. It also compares their political, 
social and economic attitudes in 1982. The table shows that, except for their gender and race, the two populations have similar demographic characteristics such as the percent of individuals that are college graduates, employed in 1997, living in the South, and from a city of a certain size. In addition, and more importantly for the generalizability of our findings, the table shows that both populations hold basically the same political, social, and economic attitudes in 1982.

The fact that the two groups are undistinguishable in terms of their pre-treatment observed characteristics leads us to believe that they are also similar in terms of their unobserved characteristics. Hence, it is likely that the estimated local average treatment effect using 2SLS reflects the average treatment effect of partisanship on attitudes for the entire population.

\section{Interacting Party Affiliation with the Level of Partisanship of the Issue}

The analysis in previous sections focused separately on each political issue that was consistently defined in 1982 and 1997, and showed evidence that party affiliation has a stronger effect on issues that tend to be more partisan. This section examines whether this pattern is systematic by combining all attitudes into one model. To do so, we treat the individual's response to each attitude as a different observation, and stack the data with 935 individuals and 16 attitudes (not counting abortion). This specification allows us to include fixed-effects for each person and political issue. The main variables in our previous analysis, however, are fixed for the individual - the person's abortion stance in 1982 and party affiliation in 1997 . Therefore, the current specification cannot identify the direct effect of party affiliation on a particular viewpoint. Instead, we test for whether the effect is systematically stronger for more partisan issues. Formally, we estimate the following model: 
$(\text { Individual Attitude })_{i a, 97}=\alpha(\text { Individual Attitude })_{i a, 82}+\beta(\text { Voted Republican })_{i, 96} \times($ Attitude

$$
\text { Partisanship) })_{a, 82}+\gamma_{i}+\mu_{a}+\varepsilon_{i a}
$$

where (Individual Attitude) $)_{\text {iat }}$ is a binary indicator for whether individual $i$ supports attitude $a$ according to the survey taken in year $t$ (where $t$ equals 1982 or 1997); (Attitude Partisanship) $)_{a, 82}$ is, as defined in Table 2, the proportion of individuals that support this attitude and voted for the Republican Party in 1980 minus the proportion of individuals that support this attitude but didn't vote for the Republican Party in 1980; $\gamma_{i}$ is an individual fixed-effect and $\mu_{a}$ is an attitude fixed-effect. For the same reasons enumerated while discussing model (1), we instrument for (Voted Republican) $)_{i, 96} \times($ Attitude

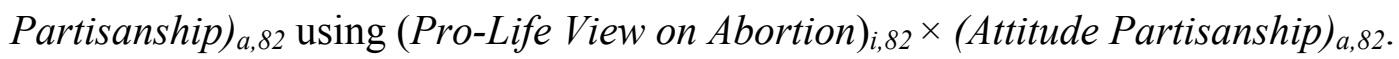

Table 11 presents the estimates of model (2). The analysis is performed with and without individual fixed effects. The results are robust for both specifications, and show that the impact of party affiliation on an individual's stance increases with the partisanship of the issue. Given that the average level of partisanship equals 0.1147 , the reduced form model in column 6 shows that a pro-life attitude on abortion increases the probability that the individual supports an average issue by 2.7 percentage points. A similar picture emerges from the 2SLS estimate in column 8, which shows that voting Republican in 1996 leads to an increase of 14 percentage points in the likelihood that the individual supports an average attitude. This is a substantial effect and is more precisely estimated than any of the 16 effects obtained when we estimate model (1) separately for each attitude.

Table 12 repeats the analysis of Table 11 for sub-samples according to key demographic characteristics. In general, the results are robust across different 
demographic groups, but the effect of party affiliation on political views is stronger for individuals who tend to be: male, college educated, white, and living outside of the South. The results are not significant for individuals residing in the South, which shows that our main findings cannot be attributed to the realignment of the southern electorate towards the Republican Party. While this realignment induced southern individuals to switch political parties, these individuals already had conservative attitudes even though they were voting for the Democrat Party. Hence, they did not need to adapt their stances in accordance with the views that were already prevalent in the Republican Party.

\section{Conclusion}

The interplay between how individuals pick their party affiliation according to their views, and how parties choose policies in the midst of electoral competition has received wide attention. However, this literature treats the views of individuals as essentially exogenous. In contrast, this paper examines the role that parties play in actually shaping the views of its supporters across a broad array of issues.

Individuals likely choose a party based on their stances on a core set of strongly held beliefs, while their stances on other issues could potentially be affected by the stance of the party leaders and other rank and file supporters. This possibility highlights the complex process whereby political parties attempt to cobble together disparate groups of supporters who come to the party based on different core issues, while shoring-up broad support by shaping the views of their supporters on the myriad of issues that are of less importance to each person.

This paper finds strong support for the idea that parties shape the views of their supporters. This issue is empirically challenging to estimate, due to the endogenous choice of party according to an individual's personal views. To estimate a causal 
relationship, we exploit a panel data set of individuals and their views on a host of issues over time, along with the increasing partisanship of the abortion issue since the early 1980 's. As abortion became an increasingly contentious issue across party lines, many individuals were practically forced to change their party in order to lend electoral support to a view that is of core importance. We find that conditional on a person's view on an issue in 1982, a person's abortion stance in 1982 has a strong and significant impact on the person's stance on the same issue in 1997, after abortion became highly partisan. Our IV estimates indicate that the mechanism is working through the effect of one's abortion stance in 1982 on their party affiliation in 1997 and not through general social attitudes. Moreover, the effect is stronger for more partisan issues, which serves as placebo test in the sense that party affiliation should not affect a person's stance on a non-partisan issue.

This systematic pattern provides support for a causal interpretation of our findings. The overall results can help us understand why and how personal opinions are so correlated across a variety of seemingly unrelated issues within the same party - a correlation which one would not expect if individuals formulated their stance on each issue independently. This strong correlation, in conjunction with our findings, suggests that an important function of a political party is not only to choose a platform in response to the views of the electorate and their supporters, but also to shape those views as well.

\section{References}

Adams, Greg D. (1997). "Abortion: Evidence of an Issue Evolution," American Journal of Political Science, 41 (3): 718-737.

Akerlof, George, and Rachel E. Kranton (2000). "Economics and Identity," The Quarterly Journal of Economics, 115 (3), 715-753. 
Altonji, Joseph G., Todd E. Elder and Christopher R. Taber (2005). "Selection on Observed and Unobserved Variables: Assessing the Effectiveness of Catholic Schools," Journal of Political Economy, 113 (1): 151-184.

Bartels, Larry M. (2002). "Beyond the Running Tally: Partisan Bias in Political Perceptions," Political Behavior, 24 (2): 117-150.

Beck, Paul, Russel Dalton, Steven Greene and Robert Huckfeldt (2002). "The Social Calculus of Voting: Interpersonal, Media, and Organizational Influences on Presidential Choices," American Political Science Review, 96(1): 57-73.

Brady, David and Edward P. Schwartz (1995). "Ideology and Interests in Congressional Voting: The Politics of Abortion in the U.S. Senate," Public Choice, 84 (1-2): 2548.

Carmines, Edward G. and James Woods (2002). "The Role of Party Activists in the Evolution of the Abortion Issue," Political Behavior, 24 (4): 361-377.

Carsey, Thomas M. and Geoffrey Layman (2006). "Changing Sides or Changing Minds? Party Conversion, Issue Conversion, and Partisan Change on the Abortion Issue," American Journal of Political Science, 35 (2): 577-597.

Converse, Philip and Gregory Markus (1979). "Plus ça Change ...: The New CPS Panel Study," American Political Science Review, 73 (1): 32-49.

Fiorina, Morris P., Samuel J. Abrams and Jeremy C. Pope (2011). Culture War? The Myth of a Polarized America, Harlow, England: Longman Publishing Group.

Fong, Christina and Erzo F.P. Luttmer (2009). "What Determines Giving to Hurricane Katrina Victims? Experimental Evidence on Racial Group Loyalty," American Economic Journal: Applied Economics, 1(2): 64-87.

Fowler, James H. and Cindy D. Kam (2007). "Beyond the Self: Social Identity, Altruism, and Political Participation," Journal of Politics, 69(3): 813-827.

Gerber, Alan S., Gregory A. Huber and Ebonya Washington (2010). "Partisan Affiliation, Partisanship, and Political Beliefs: A Field Experiment," American Political Science Review, 104 (4): 720-744.

Glaeser, Edward L., Giacomo A. M. Ponzetto and Jesse M. Shapiro (2005). " Strategic Extremism: Why Republicans and Democrats Divide on Religious Values," Quarterly Journal of Economics, 120 (4): 1283-1330. 
Green, Donald, Bradley Palmquist, and Eric Schickler (2002). Partisan Hearts and Minds. New Haven: Yale University Press.

Hare, Christopher and Keith T. Poole (2014). "The Polarization of Contemporary American Politics," Polity, 46 (3): 411-429.

Imbens, Guido W. and Joshua D. Angrist (1994). "Identification and Estimation of Local Average Treatment Effects," Econometrica, 62 (2): 467-475.

Jelen, Ted G. and Clyde Wilcox (2003). "Causes and Consequences of Public Attitudes Toward Abortion: A Review and Research Agenda," Political Research Quarterly, 56 (4): 489-500.

Jennings, Kent M., Gregory B. Markus, Richard G. Niemi, and Laura Stoker (2004). Youth Parent Socialization Panel Study, 1965-1997: Four Waves Combined, University of Michigan, Center for Political Studies/Survey Research Center, Ann Arbor, Michigan.

Killian, Mitchell and Clyde Wilcox (2008). "Do Abortion Attitudes Lead to Party Switching?" Political Research Quarterly, 61 (4): 561-573.

Klor Esteban F. and Moses Shayo (2010). "Social Identity and Preferences over Redistribution," Journal of Public Economics, 94(3-4): 269-278.

Luttmer, Erzo F.P. (2001). "Group Loyalty and the Taste for Redistribution,” Journal of Political Economy, 109 (3): 500-528.

Maxwell, Carol J. C. (2002). Pro-life Activists in America: Meaning, Motivation, and Direct Action. New York: Cambridge University Press.

McCauley, John F. (2014). "The Political Mobilization of Ethnic and Religious Identities in Africa," American Political Science Review, 108 (4), 801-816.

Mullainathan, Sendhil and Ebonya Washington (2009). "Sticking with Your Vote: Cognitive Dissonance and Political Attitudes," American Economic Journal: Applied Economics, 1 (1): 86-111.

Shayo, Moses (2009). "A Model of Social Identity with an Application to Political Economy: Nation, Class, and Redistribution," American Political Science Review, 103(2): 147-174. 
Stock, James H., Jonathan H. Wright and Motohiro Yogo (2002). "A Survey of Weak Instruments and Weak Identification in Generalized Method of Moments," Journal of Business and Economic Statistics, 20 (4): 518-529.

Tajfel, Henri and John C. Turner (1979). “An Integrative Theory of Intergroup Conflict.” In: Austing, W.G., Worchel, S. (Eds.), The Social Psychology of Intergroup Relations. Brooks/Cole, Monterey, CA, pp. 33-48.

Tajfel, Henri and John C. Turner (1986). "The Social Identity Theory of Intergroup Behavior.” In: Worchel, S., Austin, W. (Eds.), Psychology of Intergroup Relations. Nelson Hall, Chicago, pp. 7-24.

Tatalovich, Raymond (1997). The Politics of Abortion in the United States and Canada: A Comparative Study. Armonk, New York: M.E. Sharpe Publishers.

Tatalovich, Raymond and David Schier (1993). "The Persistence of Ideological Cleavage in Voting on Abortion Legislation in the House of Representatives, 1973-1988," American Politics Research, 21 (1): 125-139.

Wetstein, Matthew E. (1993). "A LISREL Model of Public Opinion on Abortion," in Understanding the New Politics of Abortion, Malcolm L. Goggin (Ed.), Newbury Park, California: Sage Publications.

Wetstein, Matthew E. (1996). Abortion Rates in the United States: The Influence of Opinion and Policy, Albany, NY: SUNY Press.

Wilcox, Clyde and Julia Riches (2002). "Pills in the Public's Mind: RU486 and the Framing of the Abortion Issue," Women \& Politics, 24 (3): 61-80. 
Figure 1: The Effects of Pro-Choice Views on Voting for Democrat or Republican Party

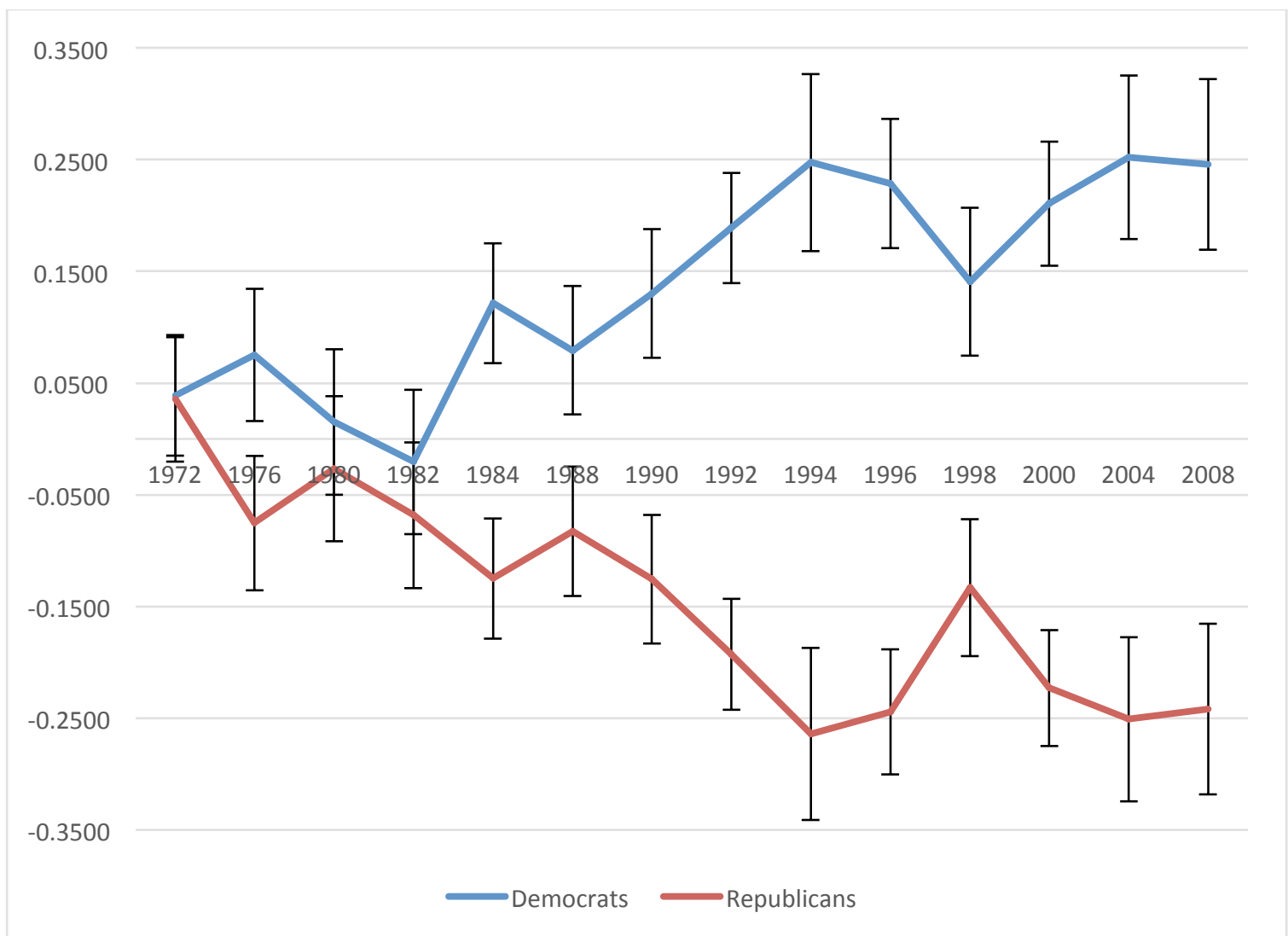

Note: Estimated coefficients of voting for the Democrat or Republican Party in presidential elections on prochoice views on abortion. The 95 percent confidence intervals around each coefficient have also been plotted. Data sources: American National Election Studies, 1972-2008. 
Figure 2: Fraction Voting Republican in 1996 Republican Voters in 1982 Only

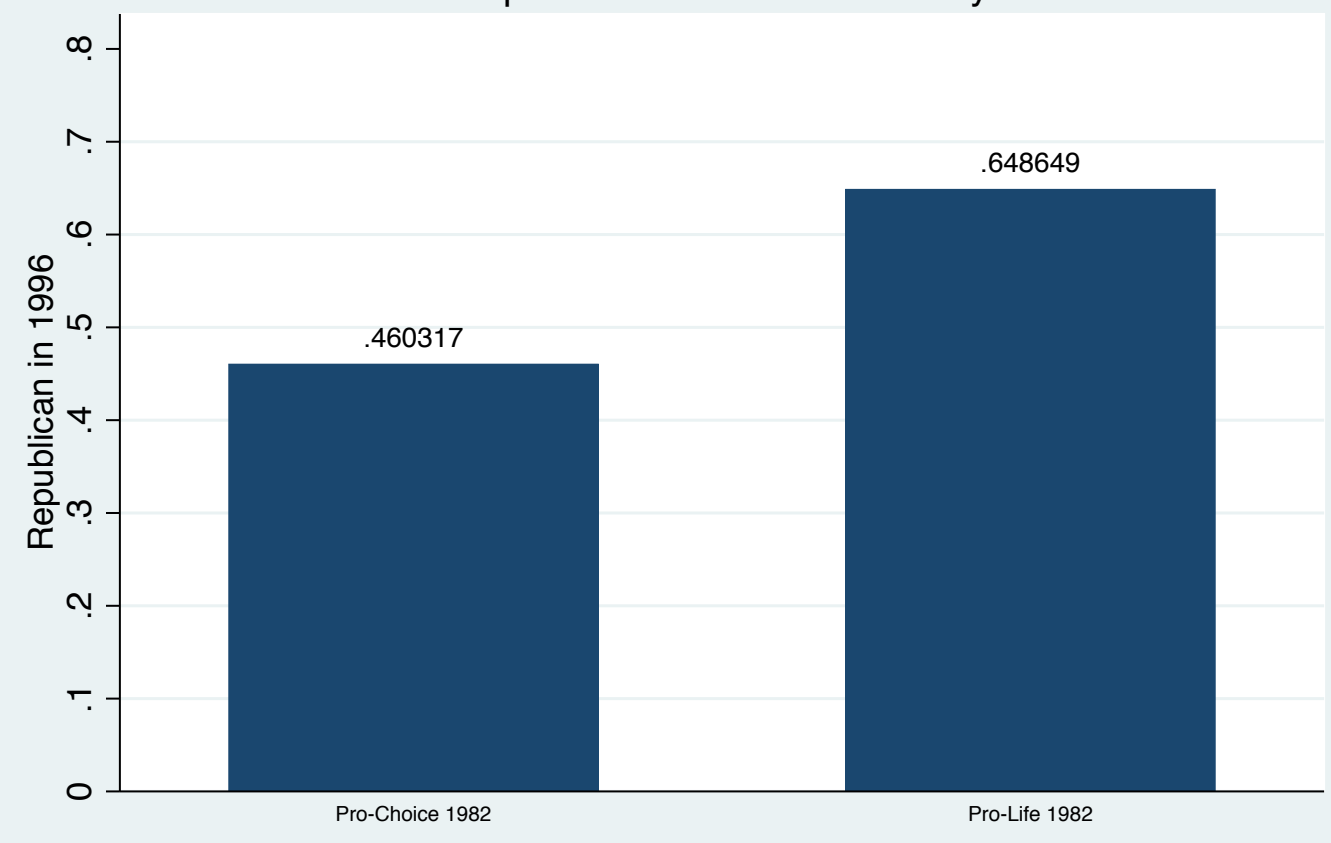

Figure 2: Fraction Voting Republican in 1996 Non-Republican Voters in 1982 Only

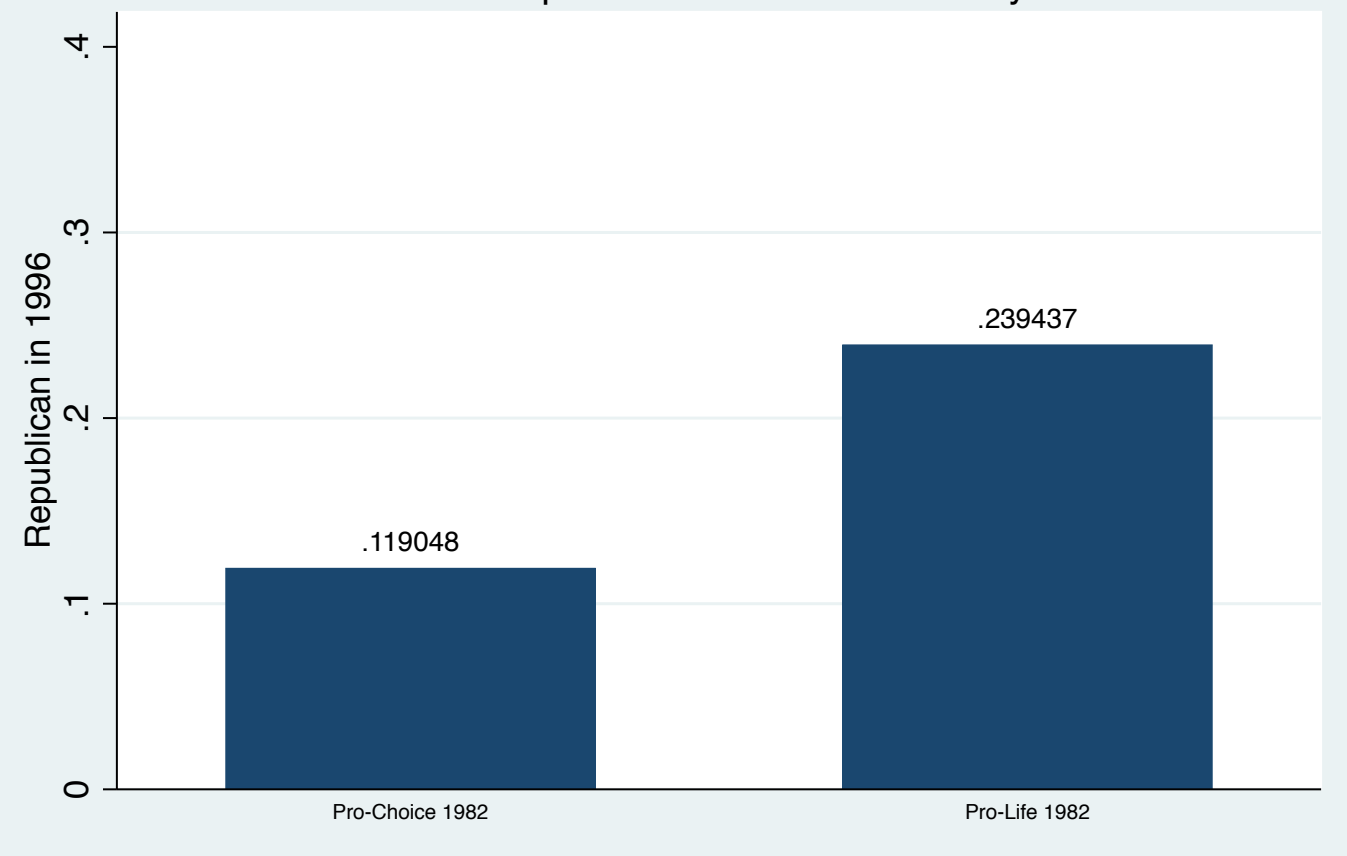


Table 1: Summary Statistics of Political, Social and Economic Attitudes

\begin{tabular}{|c|c|c|c|}
\hline & 1982 Survey & 1997 Survey & Correlation \\
\hline Pro Life & $\begin{array}{l}0.5352 \\
(0.499)\end{array}$ & $\begin{array}{l}0.5395 \\
(0.499)\end{array}$ & 0.5930 \\
\hline \multicolumn{4}{|l|}{ Political Attitudes } \\
\hline Voted Republican in previous presidential elections & $\begin{array}{l}0.5346 \\
(0.499)\end{array}$ & $\begin{array}{l}0.4002 \\
(0.490)\end{array}$ & 0.4837 \\
\hline See herself as conservative & $\begin{array}{l}0.4346 \\
(0.496)\end{array}$ & $\begin{array}{l}0.4530 \\
(0.498)\end{array}$ & 0.4881 \\
\hline \multicolumn{4}{|l|}{ Social Attitudes } \\
\hline Use of marijuana should not be legal & $\begin{array}{l}0.4696 \\
(0.499)\end{array}$ & $\begin{array}{l}0.4824 \\
(0.500)\end{array}$ & 0.4322 \\
\hline Public schools should be allowed to start each day with prayer & $\begin{array}{l}0.6289 \\
(0.483)\end{array}$ & $\begin{array}{l}0.6132 \\
(0.487)\end{array}$ & 0.5459 \\
\hline Women should not have an equal role with men & $\begin{array}{l}0.4962 \\
(0.500)\end{array}$ & $\begin{array}{l}0.4369 \\
(0.496)\end{array}$ & 0.4365 \\
\hline Respondent does not trust the government & $\begin{array}{l}0.4806 \\
(0.500)\end{array}$ & $\begin{array}{l}0.5268 \\
(0.500)\end{array}$ & 0.2398 \\
\hline \multicolumn{4}{|l|}{ Government Role in Society } \\
\hline Gvt. is not responsible of racially integrating schools & $\begin{array}{l}0.6165 \\
(0.487)\end{array}$ & $\begin{array}{l}0.4312 \\
(0.496)\end{array}$ & 0.3268 \\
\hline Government wastes a lot of money & $\begin{array}{l}0.7111 \\
(0.454)\end{array}$ & $\begin{array}{l}0.7235 \\
(0.448)\end{array}$ & 0.2845 \\
\hline Government should not help minorities & $\begin{array}{l}0.4978 \\
(0.500)\end{array}$ & $\begin{array}{l}0.5200 \\
(0.500)\end{array}$ & 0.3268 \\
\hline $\begin{array}{l}\text { Gvt. should stop crime regardless of the rights of accused of } \\
\text { committing crimes }\end{array}$ & $\begin{array}{l}0.5261 \\
(0.500)\end{array}$ & $\begin{array}{l}0.4989 \\
(0.500)\end{array}$ & 0.3283 \\
\hline Government does not pay attention to what people think & $\begin{array}{l}0.2108 \\
(0.408)\end{array}$ & $\begin{array}{l}0.2345 \\
(0.424)\end{array}$ & 0.2660 \\
\hline Gvt. should play a leading role in other countries affairs & $\begin{array}{l}0.3828 \\
(0.486)\end{array}$ & $\begin{array}{l}0.4559 \\
(0.498)\end{array}$ & 0.3421 \\
\hline \multicolumn{4}{|l|}{ Economic Attitudes } \\
\hline Gvt. should not provide jobs or ensure a good standard of living & $\begin{array}{l}0.6355 \\
(0.482)\end{array}$ & $\begin{array}{l}0.6148 \\
(0.487)\end{array}$ & 0.3475 \\
\hline Government is not run for the benefit of all & $\begin{array}{l}0.6940 \\
(0.461)\end{array}$ & $\begin{array}{l}0.7320 \\
(0.443)\end{array}$ & 0.2312 \\
\hline Unions have too much influence & $\begin{array}{l}0.7174 \\
(0.451)\end{array}$ & $\begin{array}{l}0.4449 \\
(0.497)\end{array}$ & 0.3114 \\
\hline Big Business does not have too much influence & $\begin{array}{l}0.1539 \\
(0.361)\end{array}$ & $\begin{array}{l}0.1693 \\
(0.375)\end{array}$ & 0.2431 \\
\hline Respondent supports a small government & Not Asked & $\begin{array}{c}0.5441 \\
{[0.4983]}\end{array}$ & \\
\hline
\end{tabular}

Notes: The cells present the mean and standard deviations (in parentheses) of each respective attitude. The last column presents the correlation between the 1982 and 1997 survey for each attitude. 
Table 2: Summary Statistics of Political, Social and Economic Attitudes, by Voting Record

\begin{tabular}{|c|c|c|c|c|c|c|}
\hline & \multicolumn{3}{|c|}{ View in 1982 by Party Support in 1980} & \multicolumn{3}{|c|}{ View in 1997 by Party Support in 1996} \\
\hline & Republican & Other & Difference & Republican & Other & Difference \\
\hline Pro Life & $\begin{array}{l}0.6420 \\
(0.480)\end{array}$ & $\begin{array}{l}0.4479 \\
(0.498)\end{array}$ & $\begin{array}{l}0.1941 * * * \\
{[0.0355]}\end{array}$ & $\begin{array}{l}0.7161 \\
(0.452)\end{array}$ & $\begin{array}{l}0.4235 \\
(0.495)\end{array}$ & $\begin{array}{l}0.2926 * * * \\
{[0.0346]}\end{array}$ \\
\hline \multicolumn{7}{|l|}{ Political Attitudes } \\
\hline See herself as conservative & $\begin{array}{l}0.6104 \\
(0.488)\end{array}$ & $\begin{array}{l}0.2201 \\
(0.415)\end{array}$ & $\begin{array}{l}0.3902 * * * \\
{[0.0349]}\end{array}$ & $\begin{array}{l}0.7714 \\
(0.421)\end{array}$ & $\begin{array}{l}0.2387 \\
(0.427)\end{array}$ & $\begin{array}{l}0.5327 \text { *** } \\
{[0.0310]}\end{array}$ \\
\hline \multicolumn{7}{|l|}{ Social Attitudes } \\
\hline Use of marijuana should not be legal & $\begin{array}{l}0.5667 \\
(0.496)\end{array}$ & $\begin{array}{l}0.3801 \\
(0.486)\end{array}$ & $\begin{array}{l}0.1865 * * * \\
{[0.0364]}\end{array}$ & $\begin{array}{l}0.6166 \\
(0.487)\end{array}$ & $\begin{array}{l}0.3769 \\
(0.485)\end{array}$ & $\begin{array}{l}0.2397 * * * \\
{[0.0355]}\end{array}$ \\
\hline Public schools should be allowed to start each day with prayer & $\begin{array}{l}0.6912 \\
(0.463)\end{array}$ & $\begin{array}{l}0.5563 \\
(0.498)\end{array}$ & $\begin{array}{l}0.1349 * * * \\
{[0.0376]}\end{array}$ & $\begin{array}{l}0.7431 \\
(0.438)\end{array}$ & $\begin{array}{l}0.5148 \\
(0.500)\end{array}$ & $\begin{array}{l}0.2283 * * * \\
{[0.0366]}\end{array}$ \\
\hline Women should not have an equal role with men & $\begin{array}{l}0.5679 \\
(0.496)\end{array}$ & $\begin{array}{l}0.3768 \\
(0.485)\end{array}$ & $\begin{array}{l}0.1911 \text { *** } \\
{[0.0358]}\end{array}$ & $\begin{array}{l}0.5692 \\
(0.496)\end{array}$ & $\begin{array}{l}0.3285 \\
(0.470)\end{array}$ & $\begin{array}{l}0.2407 * * * \\
{[0.0347]}\end{array}$ \\
\hline Respondent does not trust the government & $\begin{array}{l}0.4181 \\
(0.494)\end{array}$ & $\begin{array}{l}0.5666 \\
(0.496)\end{array}$ & $\begin{array}{l}-0.1485 * * * \\
{[0.0360]}\end{array}$ & $\begin{array}{l}0.6199 \\
(0.486)\end{array}$ & $\begin{array}{l}0.4614 \\
(0.499)\end{array}$ & $\begin{array}{l}0.1586 \text { *** } \\
{[0.0356]}\end{array}$ \\
\hline \multicolumn{7}{|l|}{ Government Role in Society } \\
\hline Gvt. is not responsible of racially integrating schools & $\begin{array}{l}0.7258 \\
(0.447)\end{array}$ & $\begin{array}{l}0.4671 \\
(0.500)\end{array}$ & $\begin{array}{l}0.2587^{* * *} \\
{[0.0356]}\end{array}$ & $\begin{array}{l}0.4861 \\
(0.501)\end{array}$ & $\begin{array}{l}0.3643 \\
(0.482)\end{array}$ & $\begin{array}{l}0.1218 * * * \\
{[0.0372]}\end{array}$ \\
\hline Government wastes a lot of money & $\begin{array}{l}0.7024 \\
(0.023)\end{array}$ & $\begin{array}{l}0.6949 \\
(0.461)\end{array}$ & $\begin{array}{c}0.0075 \\
{[0.0333]}\end{array}$ & $\begin{array}{l}0.7788 \\
(0.416)\end{array}$ & $\begin{array}{l}0.6757 \\
(0.469)\end{array}$ & $\begin{array}{l}0.1031 * * * \\
{[0.0323]}\end{array}$ \\
\hline Gvt. should not help minorities & $\begin{array}{l}0.6010 \\
(0.490)\end{array}$ & $\begin{array}{l}0.3743 \\
(0.485)\end{array}$ & $\begin{array}{l}0.2267 * * * \\
{[0.0358]}\end{array}$ & $\begin{array}{l}0.6417 \\
(0.480)\end{array}$ & $\begin{array}{l}0.4163 \\
(0.493)\end{array}$ & $\begin{array}{l}0.2254 \text { *** } \\
{[0.0352]}\end{array}$ \\
\hline $\begin{array}{l}\text { Gvt. should stop crime regardless of the rights of accused of } \\
\text { committing crimes }\end{array}$ & $\begin{array}{l}0.5800 \\
(0.494)\end{array}$ & $\begin{array}{l}0.4553 \\
(0.499)\end{array}$ & $\begin{array}{l}0.1247^{* * *} \\
{[0.0364]}\end{array}$ & $\begin{array}{l}0.5380 \\
(0.499)\end{array}$ & $\begin{array}{l}0.4688 \\
(0.500)\end{array}$ & $\begin{array}{c}0.0692 * \\
{[0.0364]}\end{array}$ \\
\hline Government does not pay attention to what people think & $\begin{array}{l}0.1976 \\
(0.399)\end{array}$ & $\begin{array}{l}0.2465 \\
(0.432)\end{array}$ & $\begin{array}{l}-0.0489 \\
{[0.0301]}\end{array}$ & $\begin{array}{l}0.2461 \\
(0.431)\end{array}$ & $\begin{array}{l}0.2063 \\
(0.405)\end{array}$ & $\begin{array}{c}0.0399 \\
{[0.0300]}\end{array}$ \\
\hline Gvt. should play a leading role in other countries affairs & $\begin{array}{l}0.4254 \\
(0.025)\end{array}$ & $\begin{array}{l}0.3494 \\
(0.025)\end{array}$ & $\begin{array}{l}0.0759 * * \\
{[0.0355]}\end{array}$ & $\begin{array}{l}0.4688 \\
(0.028)\end{array}$ & $\begin{array}{l}0.4707 \\
(0.023)\end{array}$ & $\begin{array}{l}-0.0020 \\
{[0.0361]}\end{array}$ \\
\hline \multicolumn{7}{|l|}{ Economic Attitudes } \\
\hline Gvt. should not provide jobs or ensure a good standard of living & $\begin{array}{l}0.7487 \\
(0.434)\end{array}$ & $\begin{array}{l}0.5045 \\
(0.501)\end{array}$ & $\begin{array}{l}0.2442 * * * \\
{[0.0349]}\end{array}$ & $\begin{array}{l}0.8258 \\
(0.380)\end{array}$ & $\begin{array}{l}0.4957 \\
(0.501)\end{array}$ & $\begin{array}{l}0.3301 * * * \\
{[0.0334]}\end{array}$ \\
\hline Gvt. is not run for the benefit of all & $\begin{array}{l}0.6020 \\
(0.490)\end{array}$ & $\begin{array}{l}0.7608 \\
(0.427)\end{array}$ & $\begin{array}{l}-0.1588 * * * \\
{[0.0340]}\end{array}$ & $\begin{array}{l}0.7573 \\
(0.429)\end{array}$ & $\begin{array}{l}0.7124 \\
(0.453)\end{array}$ & $\begin{array}{c}0.0448 \\
{[0.0326]}\end{array}$ \\
\hline Unions have too much influence & $\begin{array}{l}0.7852 \\
(0.411)\end{array}$ & $\begin{array}{l}0.6136 \\
(0.488)\end{array}$ & $\begin{array}{l}0.1715 * * * \\
{[0.0327]}\end{array}$ & $\begin{array}{l}0.5799 \\
(0.494)\end{array}$ & $\begin{array}{l}0.3674 \\
(0.483)\end{array}$ & $\begin{array}{l}0.2125 \text { *** } \\
{[0.0352]}\end{array}$ \\
\hline Big Business does not have too much influence & $\begin{array}{l}0.1858 \\
(0.389)\end{array}$ & $\begin{array}{l}0.1208 \\
(0.326)\end{array}$ & $\begin{array}{l}0.0650 * * * \\
{[0.0262]}\end{array}$ & $\begin{array}{l}0.2844 \\
(0.452)\end{array}$ & $\begin{array}{l}0.1123 \\
(0.316)\end{array}$ & $\begin{array}{l}0.1721 \text { *** } \\
{[0.0271]}\end{array}$ \\
\hline Respondent supports a small government & & & & $\begin{array}{l}0.7788 \\
(0.416)\end{array}$ & $\begin{array}{l}0.3979 \\
(0.490)\end{array}$ & $\begin{array}{l}0.3809 * * * \\
{[0.0333]}\end{array}$ \\
\hline
\end{tabular}

Notes: Standard deviations in parentheses in columns (1), (2), (4) and (5). Standard errors in brackets in columns (3) and (6). *,**, and *** represent statistical significance at 10,5 and 1 percent levels. 
Table 3: Summary Statistics on Individuals' Characteristics

\begin{tabular}{|c|c|c|}
\hline & Mean & Standard Deviation \\
\hline Males & 0.491 & 0.500 \\
\hline Whites & 0.922 & 0.269 \\
\hline College Degree & 0.481 & 0.500 \\
\hline \multirow[t]{2}{*}{ Employed in 1997} & 0.882 & 0.323 \\
\hline & Region of Birth & $\begin{array}{c}\text { Region of Residence } \\
\text { in } 1997 \\
\end{array}$ \\
\hline New England & 62 & 64 \\
\hline Mid Atlantic & 156 & 110 \\
\hline East North Central & 193 & 167 \\
\hline West North Central & 104 & 83 \\
\hline South Atlantic & 119 & 155 \\
\hline East South Central & 70 & 68 \\
\hline West South Central & 72 & 82 \\
\hline Mountain & 47 & 64 \\
\hline Pacific & 96 & 135 \\
\hline Abroad & 15 & 1 \\
\hline
\end{tabular}

Notes: Top panel presents mean and standard deviation of variables of interest. The bottom panel presents the number of individuals in each region. 
Table 4: Effect of Party Affiliation on Having Conservative Views

\begin{tabular}{|c|c|c|c|c|c|c|c|c|}
\hline \multirow[b]{2}{*}{ VARIABLES } & \multicolumn{4}{|c|}{ Without Additional Controls } & \multicolumn{4}{|c|}{ With Additional Controls } \\
\hline & $\begin{array}{l}\text { OLS } \\
(1)\end{array}$ & $\begin{array}{l}\text { Reduced Form } \\
\text { (2) }\end{array}$ & $\begin{array}{c}\text { First Stage } \\
\text { (3) }\end{array}$ & $\begin{array}{c}2 S L S \\
(4) \\
\end{array}$ & $\begin{array}{l}\text { OLS } \\
(5)\end{array}$ & $\begin{array}{c}\text { Reduced Form } \\
\text { (6) }\end{array}$ & $\begin{array}{c}\text { First Stage } \\
(7)\end{array}$ & $\begin{array}{c}2 S L S \\
(8)\end{array}$ \\
\hline Voted Republican 1996 & $\begin{array}{l}0.420^{\star \star *} \\
(0.0374)\end{array}$ & & & $\begin{array}{c}0.907^{\star * \star} \\
(0.227)\end{array}$ & $\begin{array}{l}0.417^{\star * *} \\
(0.0457)\end{array}$ & & & $\begin{array}{c}0.808^{\star * *} \\
(0.283)\end{array}$ \\
\hline Male & & & & & $\begin{array}{l}0.0790^{* *} \\
(0.0377)\end{array}$ & $\begin{array}{l}0.117^{* * *} \\
(0.0378)\end{array}$ & $\begin{array}{l}0.109^{* * *} \\
(0.0417)\end{array}$ & $\begin{array}{c}0.0331 \\
(0.0523)\end{array}$ \\
\hline White & & & & & $\begin{array}{c}0.0599 \\
(0.0739)\end{array}$ & $\begin{array}{l}0.209^{* * *} \\
(0.0723)\end{array}$ & $\begin{array}{l}0.320^{* * *} \\
(0.0592)\end{array}$ & $\begin{array}{l}-0.0677 \\
(0.116)\end{array}$ \\
\hline Employed & & & & & $\begin{array}{l}-0.0682 \\
(0.0559)\end{array}$ & $\begin{array}{l}-0.0670 \\
(0.0575)\end{array}$ & $\begin{array}{l}-0.0638 \\
(0.0673)\end{array}$ & $\begin{array}{l}-0.0468 \\
(0.0588)\end{array}$ \\
\hline Observations & 696 & 797 & 696 & 696 & 621 & 701 & 621 & 621 \\
\hline R-squared & 0.394 & 0.267 & 0.160 & 0.195 & 0.516 & 0.407 & 0.362 & 0.419 \\
\hline
\end{tabular}

Note: Specifications 5 to 8 control for current city of residence population size, current state of residence fixed effect, and state of birth fixed effect in addition to variables specified in the table. Robust standard errors in parentheses. ${ }^{*}$ indicates statistical significance at the $10 \%$ level; ${ }^{* *}$ indicates statistical significance at the $5 \%$ level; ${ }^{* * *}$ indicates statistical significance at the $1 \%$ level. 
Table 5: Effect of Party Affiliation on Social Attitudes

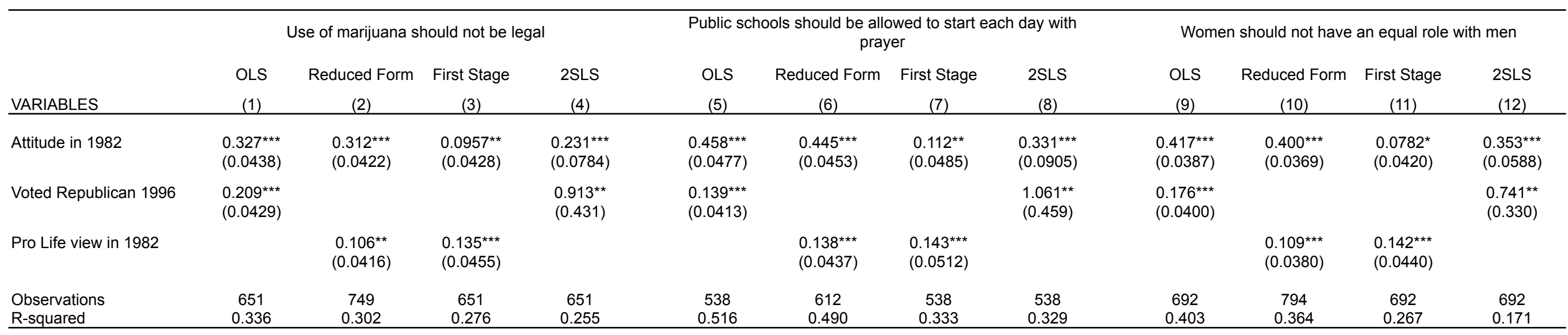

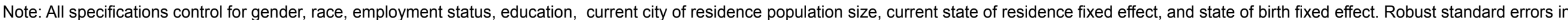
parentheses. " indicates statistical significance at the $10 \%$ level; ${ }^{* *}$ indicates statistical significance at the $5 \%$ level; ${ }^{* * *}$ indicates statistical significance at the $1 \%$ level; 
Table 6: Effect of Party Affiliation on Attitudes Regarding Role of Government

\begin{tabular}{|c|c|c|c|c|c|c|c|c|c|c|c|c|}
\hline \multirow[b]{2}{*}{ VARIABLES } & \multicolumn{4}{|c|}{ Respondent does not Trust the Government } & \multicolumn{4}{|c|}{ Government should not help minorities } & \multicolumn{4}{|c|}{$\begin{array}{c}\begin{array}{c}\text { Gvt. should not provide jobs or ensure a good standard of } \\
\text { living }\end{array}\end{array}$} \\
\hline & $\begin{array}{l}\text { OLS } \\
(1) \\
\end{array}$ & $\begin{array}{l}\text { Reduced Form } \\
\text { (2) }\end{array}$ & $\begin{array}{c}\text { First Stage } \\
(3)\end{array}$ & $\begin{array}{c}2 S L S \\
(4) \\
\end{array}$ & $\begin{array}{l}\text { OLS } \\
(5) \\
\end{array}$ & $\begin{array}{l}\text { Reduced Form } \\
\text { (6) }\end{array}$ & $\begin{array}{c}\text { First Stage } \\
(7)\end{array}$ & $\begin{array}{c}2 S L S \\
(8) \\
\end{array}$ & $\begin{array}{l}\text { OLS } \\
(9) \\
\end{array}$ & $\begin{array}{l}\text { Reduced Form } \\
(10)\end{array}$ & $\begin{array}{c}\text { First Stage } \\
(11)\end{array}$ & $\begin{array}{l}2 S L S \\
(12) \\
\end{array}$ \\
\hline Attitude in 1982 & $\begin{array}{l}0.244^{* * *} \\
(0.0409)\end{array}$ & $\begin{array}{l}0.239^{* * *} \\
(0.0380)\end{array}$ & $\begin{array}{c}0.0104 \\
(0.0387)\end{array}$ & $\begin{array}{l}0.243^{* * *} \\
(0.0428)\end{array}$ & $\begin{array}{l}0.275^{* * *} \\
(0.0417)\end{array}$ & $\begin{array}{l}0.281^{* * *} \\
(0.0383)\end{array}$ & $\begin{array}{l}0.0932^{* *} \\
(0.0399)\end{array}$ & $\begin{array}{l}0.222^{* * *} \\
(0.0561)\end{array}$ & $\begin{array}{l}0.284^{* * *} \\
(0.0445)\end{array}$ & $\begin{array}{l}0.313^{* * *} \\
(0.0411)\end{array}$ & $\begin{array}{l}0.200^{* * *} \\
(0.0428)\end{array}$ & $\begin{array}{l}0.206^{* * *} \\
(0.0700)\end{array}$ \\
\hline Voted Republican 1996 & $\begin{array}{l}0.242^{* * *} \\
(0.0434)\end{array}$ & & & $\begin{array}{l}0.530^{*} \\
(0.271)\end{array}$ & $\begin{array}{l}0.139^{* * *} \\
(0.0434)\end{array}$ & & & $\begin{array}{l}0.647^{* *} \\
(0.289)\end{array}$ & $\begin{array}{l}0.226^{* * *} \\
(0.0420)\end{array}$ & & & $\begin{array}{l}0.611^{* *} \\
(0.262)\end{array}$ \\
\hline Pro Life view in 1982 & & $\begin{array}{l}0.0736^{*} \\
(0.0401)\end{array}$ & $\begin{array}{l}0.166^{\star * *} \\
(0.0427)\end{array}$ & & & $\begin{array}{l}0.121^{* * *} \\
(0.0385)\end{array}$ & $\begin{array}{l}0.166^{\star * *} \\
(0.0425)\end{array}$ & & & $\begin{array}{l}0.106^{* * *} \\
(0.0381)\end{array}$ & $\begin{array}{l}0.166^{\star * *} \\
(0.0429)\end{array}$ & \\
\hline Observations & 695 & 800 & 695 & 695 & 687 & 783 & 687 & 687 & 646 & 732 & 646 & 646 \\
\hline R-squared & 0.240 & 0.197 & 0.258 & 0.179 & 0.290 & 0.264 & 0.278 & 0.108 & 0.341 & 0.292 & 0.297 & 0.231 \\
\hline
\end{tabular}

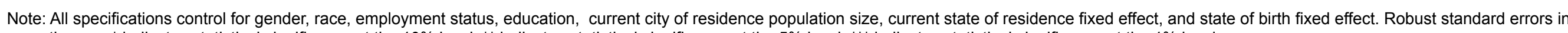
parentheses. " indicates statistical significance at the $10 \%$ level; ${ }^{* *}$ indicates statistical significance at the $5 \%$ level; ${ }^{* * *}$ indicates statistical significance at the $1 \%$ level; 
Table 7: Effect of Party Affiliation on Economic Attitudes

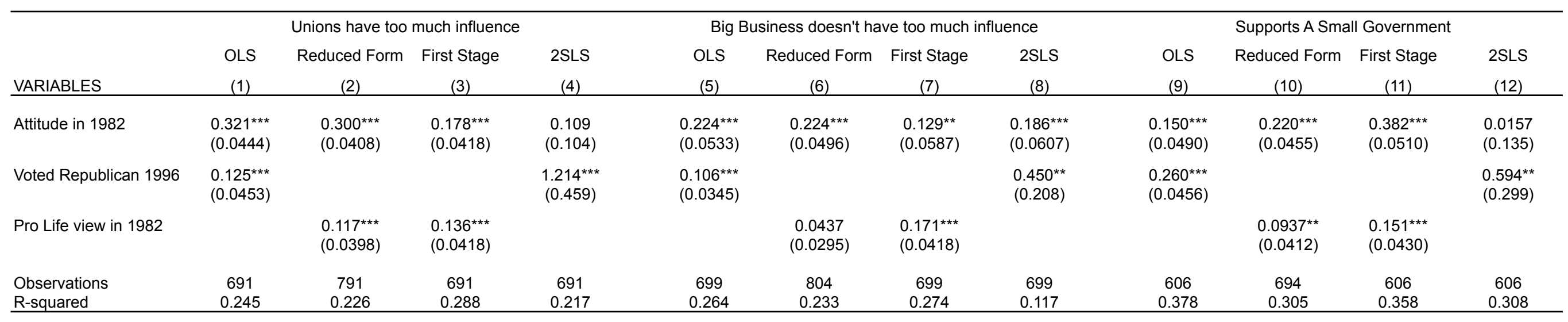

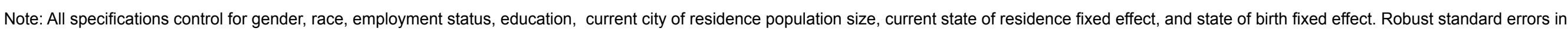
parentheses. * indicates statistical significance at the $10 \%$ level; ${ }^{* *}$ indicates statistical significance at the $5 \%$ level; ${ }^{* * *}$ indicates statistical significance at the $1 \%$ level; 
Table 8: Effect of Party Affiliation on Nonpartisan Issues

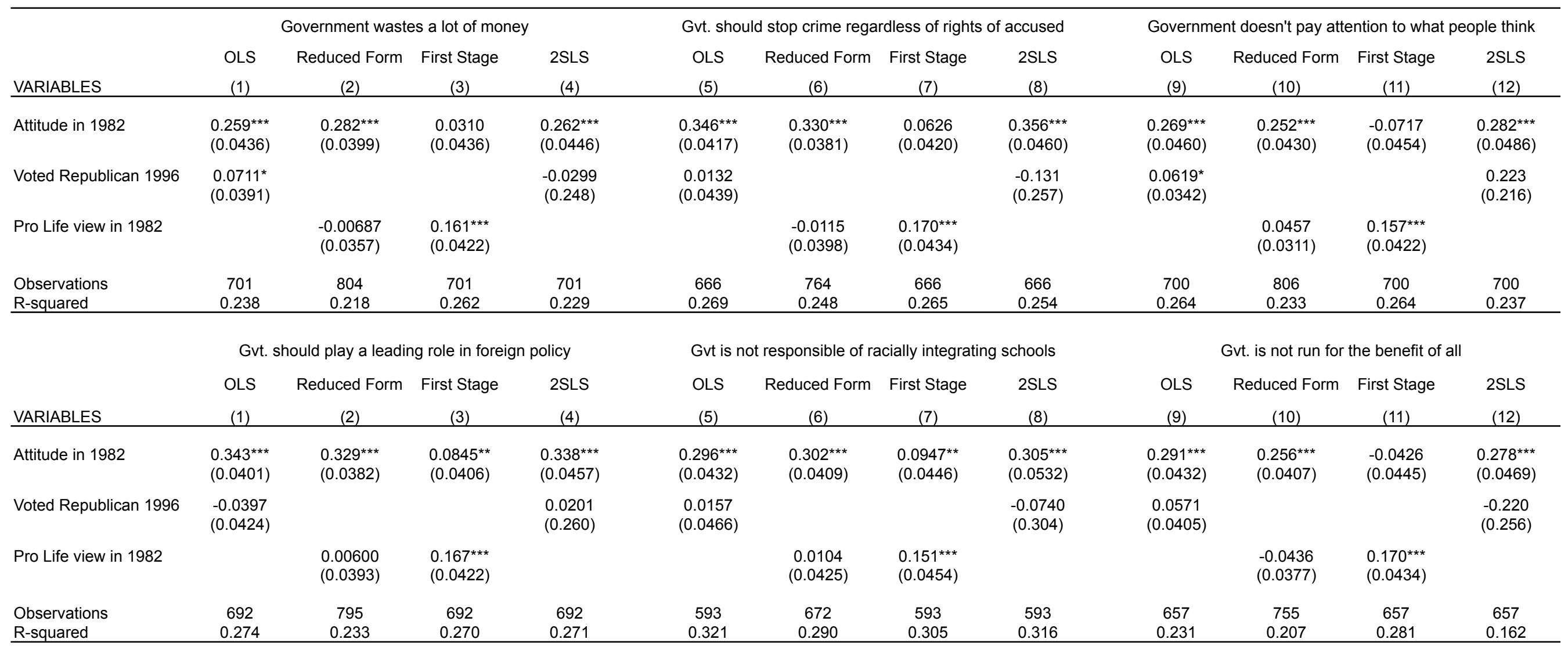

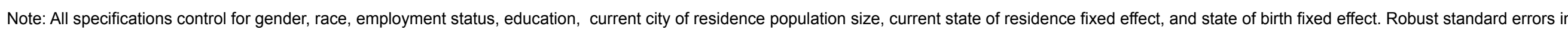
parentheses. ${ }^{*}$ indicates statistical significance at the $10 \%$ level; ${ }^{* *}$ indicates statistical significance at the $5 \%$ level; ${ }^{* * *}$ indicates statistical significance at the $1 \%$ level; 
Table 9: The Effect of Social Attitudes in 1982 on Voting Republican in 1996

\begin{tabular}{|c|c|c|c|c|c|}
\hline VARIABLES & $(1)$ & $(2)$ & (3) & (4) & (5) \\
\hline Voted Republican 1980 & $\begin{array}{l}0.322^{* * *} \\
(0.0439)\end{array}$ & $\begin{array}{l}0.359^{* * *} \\
(0.0444)\end{array}$ & $\begin{array}{l}0.332^{* * *} \\
(0.0475)\end{array}$ & $\begin{array}{l}0.339^{* * *} \\
(0.0438)\end{array}$ & $\begin{array}{l}0.324^{* * *} \\
(0.0514)\end{array}$ \\
\hline Pro Life view in 1982 & $\begin{array}{l}0.151^{* * *} \\
(0.0453)\end{array}$ & & & & $\begin{array}{c}0.121^{* *} \\
(0.0552)\end{array}$ \\
\hline Marijuana not Legal (1982) & & $\begin{array}{c}0.0858^{*} \\
(0.0446)\end{array}$ & & & $\begin{array}{c}0.0619 \\
(0.0520)\end{array}$ \\
\hline Allow Prayer in Public School (1982) & & & $\begin{array}{c}0.0395 \\
(0.0472)\end{array}$ & & $\begin{array}{l}-0.0179 \\
(0.0491)\end{array}$ \\
\hline Women not Equal Role (1982) & & & & $\begin{array}{c}0.0601 \\
(0.0435)\end{array}$ & $\begin{array}{c}0.0505 \\
(0.0508)\end{array}$ \\
\hline Constant & $\begin{array}{l}-0.157 \\
(0.179)\end{array}$ & $\begin{array}{l}-0.227 \\
(0.191)\end{array}$ & $\begin{array}{c}-0.244 \\
(0.209)\end{array}$ & $\begin{array}{l}-0.180 \\
(0.188)\end{array}$ & $\begin{array}{c}-0.294 \\
(0.218)\end{array}$ \\
\hline $\begin{array}{l}\text { Observations } \\
\text { R-squared }\end{array}$ & $\begin{array}{c}588 \\
0.353\end{array}$ & $\begin{array}{c}566 \\
0.355\end{array}$ & $\begin{array}{c}511 \\
0.369\end{array}$ & $\begin{array}{c}587 \\
0.337\end{array}$ & $\begin{array}{c}478 \\
0.406\end{array}$ \\
\hline
\end{tabular}

Note: All specifications control for gender, race, employment status, education, current city of residence population size, current state of residence fixed effect, and state of birth fixed effect. Robust standard errors in parentheses. * indicates statistical significance at the $10 \%$ level; ${ }^{* *}$ indicates statistical significance at the $5 \%$ level; ${ }^{* * *}$ indicates statistical significance at the $1 \%$ level; 
Table 10: Summary Statistics of Political, Social and Economic Attitudes, Compliers versus Rest of the Sample Population

\begin{tabular}{|c|c|c|c|}
\hline & \multicolumn{3}{|c|}{ Rest of Sample } \\
\hline & Compliers & Population & Difference \\
\hline \multicolumn{4}{|l|}{ Individual Characteristics } \\
\hline Male & $\begin{array}{l}0.4020 \\
(0.496)\end{array}$ & $\begin{array}{l}0.5018 \\
(0.500)\end{array}$ & $\begin{array}{c}0.0998 * \\
{[0.0524]}\end{array}$ \\
\hline White & $\begin{array}{l}0.9802 \\
(0.140)\end{array}$ & $\begin{array}{l}0.9145 \\
(0.280)\end{array}$ & $\begin{array}{l}-0.0657 \text { ** } \\
{[0.0283]}\end{array}$ \\
\hline Employed in 1997 & $\begin{array}{l}0.8333 \\
(0.375)\end{array}$ & $\begin{array}{l}0.8881 \\
(0.315)\end{array}$ & $\begin{array}{r}0.0548 \\
{[0.0338]}\end{array}$ \\
\hline College Degree & $\begin{array}{l}0.4902 \\
(0.502)\end{array}$ & $\begin{array}{l}0.4802 \\
(0.500)\end{array}$ & $\begin{array}{r}-0.0100 \\
{[0.0525]}\end{array}$ \\
\hline Size of City of Residency in 1982 & $\begin{array}{l}3.9457 \\
(2.478)\end{array}$ & $\begin{array}{l}4.2919 \\
(2.648)\end{array}$ & $\begin{array}{r}0.3462 \\
{[0.2907]}\end{array}$ \\
\hline Born in a Southern State & $\begin{array}{l}0.2647 \\
(0.443)\end{array}$ & $\begin{array}{l}0.2809 \\
(0.450)\end{array}$ & $\begin{array}{r}0.0162 \\
{[0.0471]}\end{array}$ \\
\hline \multicolumn{4}{|l|}{ Political Attitudes in 1982} \\
\hline See herself as conservative & $\begin{array}{l}0.4545 \\
(0.501)\end{array}$ & $\begin{array}{l}0.4322 \\
(0.496)\end{array}$ & $\begin{array}{r}-0.0223 \\
{[0.0560]}\end{array}$ \\
\hline \multicolumn{4}{|l|}{ Social Attitudes in 1982} \\
\hline Use of marijuana should not be legal & $\begin{array}{l}0.4479 \\
(0.500)\end{array}$ & $\begin{array}{l}0.4722 \\
(0.500)\end{array}$ & $\begin{array}{r}0.0243 \\
{[0.0540]}\end{array}$ \\
\hline Public schools should be allowed to start each day with prayer & $\begin{array}{l}0.6092 \\
(0.491)\end{array}$ & $\begin{array}{l}0.6313 \\
(0.483)\end{array}$ & $\begin{array}{r}0.0221 \\
{[0.0549]}\end{array}$ \\
\hline Women should not have an equal role with men & $\begin{array}{l}0.4752 \\
(0.502)\end{array}$ & $\begin{array}{l}0.4988 \\
(0.500)\end{array}$ & $\begin{array}{r}0.0235 \\
{[0.0528]}\end{array}$ \\
\hline Respondent does not trust the government & $\begin{array}{l}0.4412 \\
(0.499)\end{array}$ & $\begin{array}{l}0.4854 \\
(0.500)\end{array}$ & $\begin{array}{r}0.0443 \\
{[0.0525]}\end{array}$ \\
\hline \multicolumn{4}{|l|}{ Government Role in Society in 1982} \\
\hline Gvt. is not responsible of racially integrating schools & $\begin{array}{l}0.5474 \\
(0.500)\end{array}$ & $\begin{array}{l}0.6252 \\
(0.484)\end{array}$ & $\begin{array}{r}0.0778 \\
{[0.0529]}\end{array}$ \\
\hline Government wastes a lot of money & $\begin{array}{l}0.7255 \\
(0.448)\end{array}$ & $\begin{array}{l}0.7093 \\
(0.454)\end{array}$ & $\begin{array}{r}-0.0162 \\
{[0.0476]}\end{array}$ \\
\hline Gvt. should not help minorities & $\begin{array}{l}0.5686 \\
(0.498)\end{array}$ & $\begin{array}{l}0.4888 \\
(0.500)\end{array}$ & $\begin{array}{r}-0.0798 \\
{[0.0525]}\end{array}$ \\
\hline $\begin{array}{l}\text { Gvt. should stop crime regardless of the rights of accused of } \\
\text { committing crimes }\end{array}$ & $\begin{array}{l}0.5700 \\
(0.498)\end{array}$ & $\begin{array}{l}0.5206 \\
(0.500)\end{array}$ & $\begin{array}{r}-0.0494 \\
{[0.0530]}\end{array}$ \\
\hline Government does not pay attention to what people think & $\begin{array}{l}0.2157 \\
(0.413)\end{array}$ & $\begin{array}{l}0.2101 \\
(0.408)\end{array}$ & $\begin{array}{r}-0.0055 \\
{[0.0428]}\end{array}$ \\
\hline Gvt. should play a leading role in other countries affairs & $\begin{array}{l}0.4300 \\
(0.498)\end{array}$ & $\begin{array}{l}0.3770 \\
(0.485)\end{array}$ & $\begin{array}{r}-0.0530 \\
{[0.0515]}\end{array}$ \\
\hline \multicolumn{4}{|l|}{ Economic Attitudes in 1982} \\
\hline Gvt. should not provide jobs or ensure a good standard of living & $\begin{array}{l}0.6869 \\
(0.466)\end{array}$ & $\begin{array}{l}0.6290 \\
(0.483)\end{array}$ & $\begin{array}{r}-0.0579 \\
{[0.0514]}\end{array}$ \\
\hline Gvt. is not run for the benefit of all & $\begin{array}{l}0.6162 \\
(0.489)\end{array}$ & $\begin{array}{l}0.7036 \\
(0.457)\end{array}$ & $\begin{array}{c}0.0874 * \\
{[0.0491]}\end{array}$ \\
\hline Unions have too much influence & $\begin{array}{l}0.7549 \\
(0.432)\end{array}$ & $\begin{array}{l}0.7127 \\
(0.453)\end{array}$ & $\begin{array}{r}-0.0422 \\
{[0.0473]}\end{array}$ \\
\hline Big Business does not have too much influence & $\begin{array}{l}0.1373 \\
(0.346)\end{array}$ & $\begin{array}{l}0.1560 \\
(0.363)\end{array}$ & $\begin{array}{r}0.0187 \\
{[0.0379]}\end{array}$ \\
\hline
\end{tabular}

Notes: Standard deviations in parentheses in columns (1) and (2). Standard errors in brackets in column (3). *, **, and *** represent statistical significance at 10,5 and 1 percent levels. 
Table 11: Effect of Party Affiliation and Partisanship of Issues on Political Attitudes

\begin{tabular}{|c|c|c|c|c|c|c|c|c|}
\hline \multirow[b]{2}{*}{ VARIABLES } & \multicolumn{4}{|c|}{ Without Fixed Effects } & \multicolumn{4}{|c|}{ With Individual and Attitude Fixed Effects } \\
\hline & $\begin{array}{l}\text { OLS } \\
(1) \\
\end{array}$ & $\begin{array}{c}\text { Reduced Form } \\
\text { (2) }\end{array}$ & $\begin{array}{c}\text { First Stage } \\
(3) \\
\end{array}$ & $\begin{array}{c}2 S L S \\
(4) \\
\end{array}$ & $\begin{array}{l}\text { OLS } \\
(5) \\
\end{array}$ & $\begin{array}{l}\text { Reduced Form } \\
(6) \\
\end{array}$ & $\begin{array}{c}\text { First Stage } \\
(7) \\
\end{array}$ & $\begin{array}{c}2 S L S \\
(8) \\
\end{array}$ \\
\hline Attitude in 1982 & $\begin{array}{c}0.371^{* * *} \\
(0.00916)\end{array}$ & $\begin{array}{c}0.371^{* * *} \\
(0.00845)\end{array}$ & $\begin{array}{l}0.026^{* * *} \\
(0.0018)\end{array}$ & $\begin{array}{c}0.368^{* * *} \\
(0.00996)\end{array}$ & $\begin{array}{l}0.303^{* * *} \\
(0.0101)\end{array}$ & $\begin{array}{c}0.299^{* * *} \\
(0.00940)\end{array}$ & $\begin{array}{l}0.020^{* * *} \\
(0.0020)\end{array}$ & $\begin{array}{l}0.280^{* * *} \\
(0.0131)\end{array}$ \\
\hline $\begin{array}{l}\text { Voted Republican } 1996 \text { (interacted with partisanship of } \\
\text { issue) }\end{array}$ & $\begin{array}{l}0.402^{* * *} \\
(0.0408)\end{array}$ & & & $\begin{array}{l}0.633^{* * *} \\
(0.0962)\end{array}$ & $\begin{array}{l}0.317^{* * *} \\
(0.0627)\end{array}$ & & & $\begin{array}{r}1.234^{* * *} \\
(0.358)\end{array}$ \\
\hline $\begin{array}{l}\text { Pro Life view in } 1982 \text { (interacted with partisanship of } \\
\text { issue) }\end{array}$ & & $\begin{array}{l}0.231^{* * *} \\
(0.0366)\end{array}$ & $\begin{array}{l}0.417^{* * *} \\
(0.0070)\end{array}$ & & & $\begin{array}{l}0.238^{* * *} \\
(0.0590)\end{array}$ & $\begin{array}{l}0.1986^{* * *} \\
(0.0338)\end{array}$ & \\
\hline Individual Fixed Effects & No & No & No & No & Yes & Yes & Yes & Yes \\
\hline Attitude Fixed Effects & No & No & No & No & Yes & Yes & Yes & Yes \\
\hline Number of Individuals & 802 & 923 & 791 & 791 & 802 & 923 & 791 & 791 \\
\hline Observations & 11,989 & 13,712 & 11,825 & 11,825 & 11,989 & 13,712 & 11,825 & 11,825 \\
\hline R-squared & 0.165 & 0.154 & 0.243 & 0.163 & 0.215 & 0.205 & 0.4349 & 0.177 \\
\hline
\end{tabular}

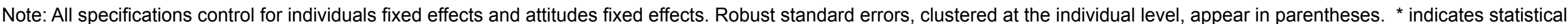
significance at the $10 \%$ level; ${ }^{* *}$ indicates statistical significance at the $5 \%$ level; ${ }^{* *}$ indicates statistical significance at the $1 \%$ level; 
Table 12: Effect of Party Affiliation and Partisanship of Issues on Political Attitudes, by different Subgroups of the Population

\begin{tabular}{|c|c|c|c|c|c|c|c|c|}
\hline \multirow[b]{3}{*}{ VARIABLES } & \multicolumn{4}{|c|}{ Gender } & \multicolumn{4}{|c|}{ Race } \\
\hline & \multicolumn{2}{|c|}{ Males } & \multicolumn{2}{|c|}{ Females } & \multicolumn{2}{|c|}{ Whites } & \multicolumn{2}{|c|}{ Blacks } \\
\hline & Reduced Form & 2SLS & Reduced Form & 2SLS & Reduced Form & 2SLS & Reduced Form & 2SLS \\
\hline Attitude in 1982 & $\begin{array}{c}0.3040^{* * *} \\
(0.0144)\end{array}$ & $\begin{array}{c}0.2662^{\star * *} \\
(0.0233)\end{array}$ & $\begin{array}{c}0.3041^{* * *} \\
(0.0145)\end{array}$ & $\begin{array}{c}0.2873^{* * *} \\
(0.0167)\end{array}$ & $\begin{array}{c}0.3027^{* * *} \\
(0.0105)\end{array}$ & $\begin{array}{c}0.2831^{* * *} \\
(0.0128)\end{array}$ & $\begin{array}{c}0.2586^{* * *} \\
(0.0364)\end{array}$ & $\begin{array}{c}0.2279^{* * *} \\
(0.0444)\end{array}$ \\
\hline $\begin{array}{l}\text { Voted Republican } 1996 \text { (interacted with } \\
\text { partisanship of issues) }\end{array}$ & & $\begin{array}{l}1.7329^{* \star *} \\
(0.7095)\end{array}$ & & $\begin{array}{l}0.8861^{* *} \\
(0.4263)\end{array}$ & & $\begin{array}{l}1.0986^{* * *} \\
(0.3401)\end{array}$ & & $\begin{array}{c}0.5258 \\
(0.4714)\end{array}$ \\
\hline $\begin{array}{l}\text { Pro Life view in } 1982 \text { (interacted with } \\
\text { partisanship of issue) }\end{array}$ & $\begin{array}{c}0.2734^{* * *} \\
(0.0927)\end{array}$ & & $\begin{array}{l}0.1953^{* *} \\
(0.0883)\end{array}$ & & $\begin{array}{c}0.2328^{* * *} \\
(0.0661)\end{array}$ & & $\begin{array}{c}0.2872 \\
(0.2002)\end{array}$ & \\
\hline $\begin{array}{l}\text { Number of Individuals } \\
\text { Observations } \\
\text { R-squared }\end{array}$ & $\begin{array}{c}386 \\
5,819 \\
0.2082 \\
\end{array}$ & $\begin{array}{c}386 \\
5,819 \\
0.149 \\
\end{array}$ & $\begin{array}{c}405 \\
6,006 \\
0.2143 \\
\end{array}$ & $\begin{array}{c}405 \\
6,006 \\
0.1977 \\
\end{array}$ & $\begin{array}{c}725 \\
10,834 \\
0.2072 \\
\end{array}$ & $\begin{array}{c}725 \\
10,834 \\
0.1787 \\
\end{array}$ & $\begin{array}{c}62 \\
930 \\
0.2837 \\
\end{array}$ & $\begin{array}{c}62 \\
930 \\
0.2299 \\
\end{array}$ \\
\hline \multirow{2}{*}{ R-squared } & \multicolumn{4}{|c|}{ Education } & \multicolumn{4}{|c|}{ Region of Residence } \\
\hline & \multicolumn{2}{|c|}{ College Degree } & \multicolumn{2}{|c|}{ Without College Degree } & \multicolumn{2}{|c|}{ South } & \multicolumn{2}{|c|}{ No South } \\
\hline VARIABLES & Reduced Form & 2SLS & Reduced Form & $2 S L S$ & Reduced Form & 2SLS & Reduced Form & $2 S L S$ \\
\hline Attitude in 1982 & $\begin{array}{c}0.3125^{\star * *} \\
(0.0154)\end{array}$ & $\begin{array}{c}0.2934^{* * *} \\
(0.0174)\end{array}$ & $\begin{array}{c}0.2928^{* * *} \\
(0.0136)\end{array}$ & $\begin{array}{c}0.2677^{* * *} \\
(0.0182)\end{array}$ & $\begin{array}{c}0.2788^{* * *} \\
(0.0182)\end{array}$ & $\begin{array}{c}0.2797^{* * *} \\
(0.0192)\end{array}$ & $\begin{array}{c}0.3177^{* * *} \\
(0.0123)\end{array}$ & $\begin{array}{r}0.2699^{* * *} \\
(0.0208)\end{array}$ \\
\hline $\begin{array}{l}\text { Voted Republican } 1996 \text { (interacted with } \\
\text { partisanship of issues) }\end{array}$ & & $\begin{array}{l}1.3035^{\star \star *} \\
(0.4727)\end{array}$ & & $\begin{array}{l}1.0669^{* * *} \\
(0.4391)\end{array}$ & & $\begin{array}{l}-0.0501 \\
(0.4077)\end{array}$ & & $\begin{array}{r}2.3348^{* * *} \\
(0.7166)\end{array}$ \\
\hline $\begin{array}{l}\text { Pro Life view in } 1982 \text { (interacted with } \\
\text { partisanship of issue) }\end{array}$ & $\begin{array}{c}0.2796^{* * *} \\
(0.0949)\end{array}$ & & $\begin{array}{c}0.2349^{* * *} \\
(0.0885)\end{array}$ & & $\begin{array}{l}-0.0133 \\
(0.1080)\end{array}$ & & $\begin{array}{c}0.3678^{* * *} \\
(0.0786)\end{array}$ & \\
\hline $\begin{array}{l}\text { Number of Individuals } \\
\text { Observations } \\
\text { R-squared }\end{array}$ & $\begin{array}{c}369 \\
5,493 \\
0.2198\end{array}$ & $\begin{array}{c}369 \\
5,493 \\
0.189\end{array}$ & $\begin{array}{c}422 \\
6,332 \\
0.203\end{array}$ & $\begin{array}{c}422 \\
6,332 \\
0.1767\end{array}$ & $\begin{array}{c}260 \\
3,897 \\
0.1883\end{array}$ & $\begin{array}{c}260 \\
3,897 \\
0.1775\end{array}$ & $\begin{array}{c}531 \\
7,928 \\
0.2194\end{array}$ & $\begin{array}{c}531 \\
7,928 \\
0.1157\end{array}$ \\
\hline
\end{tabular}

Note: 2SLS estimates of model (3). All specifications control for individuals fixed effects and attitudes fixed effects. Robust standard errors, clustered at the individual level, appear in parentheses. ${ }^{*}$ indicates statistical significance at the $10 \%$ level; ${ }^{* *}$ indicates statistical significance at the $5 \%$ level; ${ }^{* * *}$ indicates statistical significance at the $1 \%$ level; 


\section{Appendix:}

This appendix updates the evidence in Adams (1997). Figures 4 and 5 in Adams (1997) use data from the General Social Surveys (GSS) between 1972 and 1994 to build those figures. The figures focus on the GSS six available questions probing respondents' attitudes about a woman's right to perform a legal abortion under various circumstances. The circumstances covered are (i) the woman became pregnant as a result of rape, (ii) the woman's own health is seriously endangered by the pregnancy, (iii) there is a strong chance of a serious defect in the baby, (iv) the woman is married and does not want to have any more children, (v) the family has a very low income and cannot afford any more children, and (vi) the woman is not married and does not want to marry the man. Figure A.1 presents the percentage of the survey population that agrees with the right of the woman to perform an abortion for every scenario and every available year (these questions were not asked in 1979, 1981, 1986, 1992, 1995, 1997 and 1999, 2001 and 2003). This figure extends Figure 4 in Adams (1997) from 1972-1994 to 1972-2004.

Figure A.1 shows that the survey population is clustered into two main groups. Over 80 percent of all respondents believe that abortion should be legal in cases where the woman became pregnant as a result of rape, the woman's own health is seriously endangered by the pregnancy, and there is a strong chance of a serious defect in the baby. That said, only roughly 45 percent of all respondents believe that abortion should be legal in the other three more controversial uses of abortion. This figure also shows that views on abortion (at least at the aggregate level) are constant over time.

Figure A.2 extends Adams (1997) measure of partisan polarization over the abortion issue dimension until 2004. To build this figure, Adams (1997) assigns a value 
of one to every answer in favor of abortion, a value of half when the respondent did not answer a question, and a value of zero when the respondent opposes the legalization of abortion under the given scenario. Respondents that did not answer any of the six questions are omitted from the sample. Adams (1997) then computes the average yearly abortion score for individuals that identify themselves as Democrats and individuals that identify themselves as Republicans. The figure plots the difference between these two averages.

Figure A.2 depicts the substantial changes that partisans of both parties underwent on their attitudes regarding abortion over time. The figure shows that until 1987 Republican respondents had a more pro-choice attitude than Democrat respondents. This completely changes from 1988 and onwards. Since 1988 Democrats masses are more prochoice than Republican masses, and the difference between the two groups grows over time. Interestingly, according to Adams (1997), the political parties started this divergence over abortion views several years earlier, around the beginning of the $80 \mathrm{~s}$.

In summary, for our purposes, Figure A.2 provides additional supporting evidence that the abortion issue brought to a realignment of the electorate across party lines during the late $80 \mathrm{~s}$ and early $90 \mathrm{~s}$. While the correlation between views on abortion and party identification does not appear to be substantive in 1982, by 1997 it is clear that supporters of the Democrat Party have more pro-choice views than supporters of the Republican Party. Since, as already stated above, individuals do not tend to change their views on abortion, we believe that the pattern observed in Figure A.2 is due in part to individuals changing their party identification because of their views on abortion. 
Figure A.1: Support for Abortion Rights among Survey Respondents

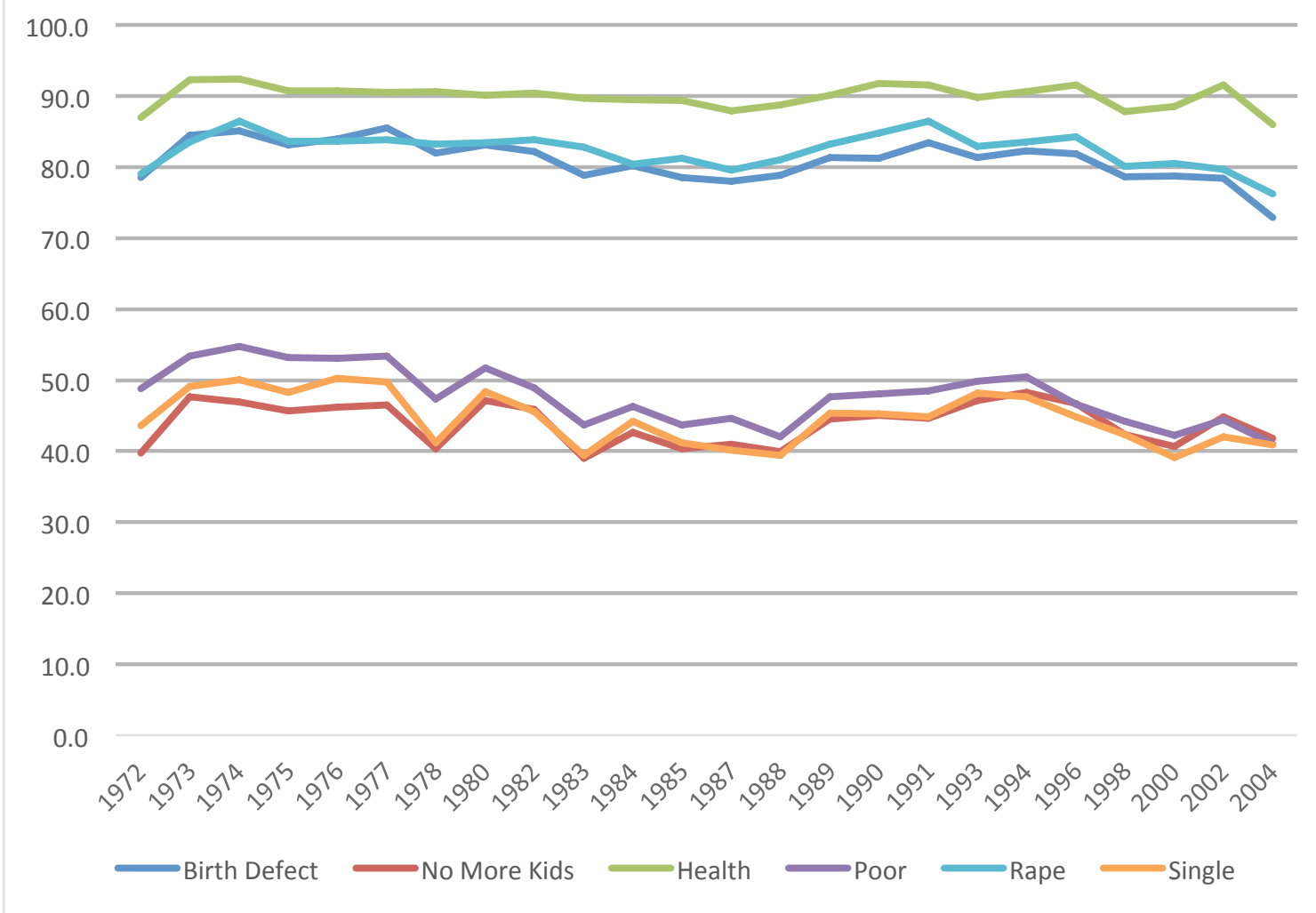

Note: Using General Social Survey, 1972-2004 
Figure A.2: Difference Between Average Mass Democrat and Average Mass Republican Pro-Choice Scores

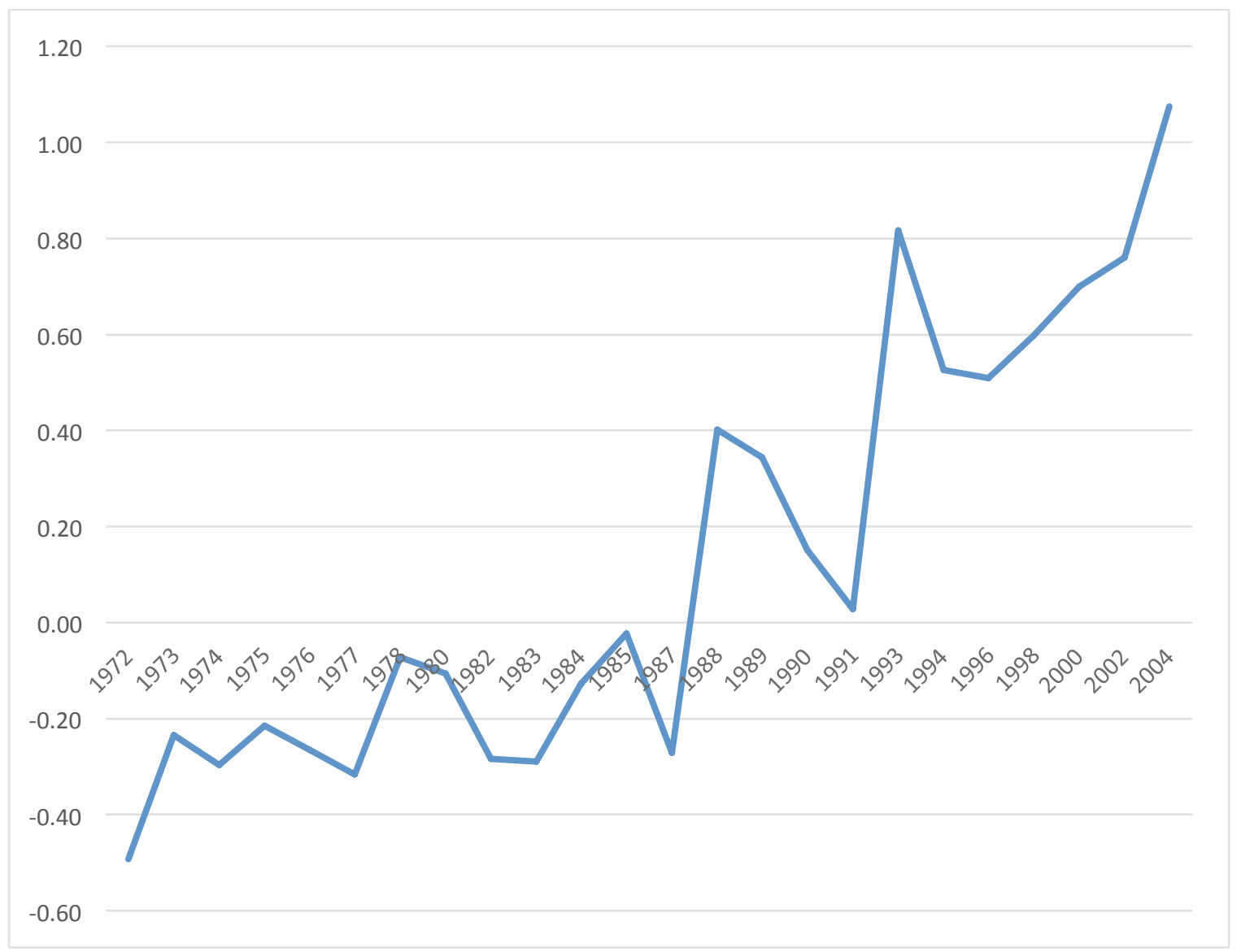

Note: Using General Social Survey, 1972-2004. See text for description of computations. 